\title{
Review
}

\section{MXenes as noble-metal-alternative co-catalysts in photocatalysis}

\author{
Kaining Li a, Sushu Zhang a, Yuhan Li b,\#, Jiajie Fan c, Kangle Lv a,* \\ a Key Laboratory of Catalysis and Energy Materials Chemistry of Ministry of Enducation, College of Resources and Environmental Science, South-Central \\ University for Nationalities, Wuhan 430074, Hubei, China \\ ${ }^{\mathrm{b}}$ Engineering Research Center for Waste Oil Recovery Technology and Equipment, Ministry of Education, Chongqing Key Laboratory of Catalysis and New \\ Environmental Materials, Chongqing Technology and Business University, Chongqing 400067, China \\ c School of Materials Science and Engineering, Zhengzhou University, Zhengzhou 450001, Henan, China
}

\section{A R T I C L E I N F O}

\section{Article history:}

Received 27 March 2020

Accepted 2 May 2020

Published 5 January 2021

\section{Keywords:}

MXenes

Photocatalytic degradation

Hydrogen production

$\mathrm{CO}_{2}$ reduction

Nitrogen fixation

\begin{abstract}
A B S T R A C T
Photocatalysis has become a focal point in research as a clean and sustainable technology with the potential to solve environmental problems and energy crises. The loading of noble-metal co-catalysts can substantially improve the photocatalytic efficiency of semiconductors. Because the high cost and scarcity of noble metals markedly limit their large-scale applications, finding a noble-metal-alternative co-catalyst is crucial. MXene, a novel 2D transition metal material, has attracted considerable attention as a promising substitute for noble metal co-catalysts owing to its cost-efficiency, unique 2D layered structure, and excellent electrical, optical, and thermodynamic properties. This review focuses on the latest advancements in research on MXenes as co-catalysts in relatively popular photocatalytic applications (hydrogen production, $\mathrm{CO}_{2}$ reduction, nitrogen fixation, and organic pollutant oxidation). The synthesis methods and photocatalytic mechanisms of MXenes as co-catalysts are also summarized according to the type of MXene-based material. Finally, the crucial opportunities and challenges in the prospective development of MXene-based photocatalysts are outlined. We emphasize that modern techniques should be used to demonstrate the effects of MXenes on photocatalysis and that the photocatalytic activity of MXene-based photocatalysts can be further improved using defective engineering and recent phenomena such as the localized surface plasmon resonance effect and single-atom catalysis.
\end{abstract}

(C) 2021, Dalian Institute of Chemical Physics, Chinese Academy of Sciences. Published by Elsevier B.V. All rights reserved.

\section{Introduction}

With the development of human industrialization, the excessive use of limited fossil fuel resources will lead to energy shortages, environmental contamination, and abnormal cli- matic variations $[1,2]$. It is, therefore, necessary to develop an environmentally friendly and sustainable technology to address these problems. Among the diverse advanced technologies, photocatalysis is regarded as one of the cleanest technologies and one that exhibits great potential in various areas of

\footnotetext{
* Corresponding author. Tel: +86-27-67841369; Fax: +86-27-67843918; E-mail: lvkangle@mail.scuec.edu.cn

\# Corresponding author. Tel: +86-23-62768317; E-mail: lyhctbu@126.com

This work was supported by the National Natural Science Foundation of China (51672312, 51808080, 21373275), the Fundamental Research Funds for the Central Universities, South-Central University for Nationalities (CZT20016), China "Post-Doctoral Innovative Talent Support Program" (BX20180056), the Natural Science Foundation Project of CQ CSTC (cstc2018jcyjA3794), China Postdoctoral Science Foundation (2018M643788XB), Science and Technology Research Project of Chongqing Education Commission Foundation (KJQN20180082, KJZDK201800801), Venture \& Innovation Support Program for Chongqing Overseas Returnees (cx2018130), and Chongqing Technology and Business University Research Foundation Project (1856039).
} DOI: 10.1016/S1872-2067(20)63630-0 | http://www.sciencedirect.com/science/journal/18722067 | Chin. J. Catal., Vol. 42, No. 1, January 2021 
application, such as $\mathrm{H}_{2} \mathrm{O}$ splitting [3-5], $\mathrm{CO}_{2}$ reduction [6,7], and the oxidation of organic pollutants [8]. As a rule, a photocatalytic reaction includes three processes: (1) light harvest by photocatalysts to generate photoexcited carriers, (2) carrier isolation and transfer to the surface of the photocatalyst, and (3) carrier-induced surface redox reactions. The photocatalytic activity is determined by these three processes. Most conventional photocatalysts, such as $\mathrm{TiO}_{2}, \mathrm{ZnIn}_{2} \mathrm{~S}_{4}$, and $\mathrm{g}-\mathrm{C}_{3} \mathrm{~N}_{4}$, demonstrate poor photocatalytic efficiency because their photo-triggered electron-hole pairs rapidly recombine [9-11]. Loading co-catalysts can effectively improve the efficiency of carrier separation. The co-catalyst can not only act as an electron sink to enhance the charge separation ability but can also provide abundant active sites [12-14]. Many noble metals, such as Pt [15], $\mathrm{Ag}$ [16], and $\mathrm{Au}$ [17], have been considered as efficient co-catalysts for photocatalytic reactions. However, the application of precious metal co-catalysts is limited by their high price and scarcity. Thus, there is an urgent need for designing high efficiency, low cost noble-metal-alternative co-catalysts.

A neotype of 2D hierarchical transition metal carbides, nitrides, or carbonitrides (MXenes) has been synthesized by selective etching of the A-element of 3D ternary compounds (known as MAX phases). M denotes an early transition metal element, such as Sc, Ti, and V; A is one of the elements of IIIA and IVA; and $\mathrm{X}$ stands for the $\mathrm{C} / \mathrm{N}$ element [18]. The formula for MXenes is $\mathrm{M}_{n+1} \mathrm{X}_{n}$ or $\mathrm{M}_{n+1} \mathrm{X}_{n} \mathrm{~T}_{X}$ (T represents surface functional groups such as $-\mathrm{O},-\mathrm{F}$, and $-\mathrm{OH}$ ), and $\mathrm{n}$ ranges from 1 to 3 , which determines the number of atomic layers in the unit cell $[19,20]$.

Figure 1 illustrates some typical structured MXenes $\left(\mathrm{M}_{2} \mathrm{XT}_{x}\right.$, $\mathrm{M}_{3} \mathrm{X}_{2} \mathrm{~T}_{X}$, and $\mathrm{M}_{4} \mathrm{X}_{3} \mathrm{~T}_{x}$ ), in which the top row shows structures of mono-M MXenes that cover the $X$ elements [21]. For the solid solution phase, two kinds of $M$ transition metals are randomly distributed in the MXenes (see the second row in Fig. 1). Ordered double-M MXenes are shown in the third row, where single or double layers of one $\mathrm{M}$ metal are sandwiched between layers of another M metal [22]. Although other 2D carbon-based materials such as graphene and graphdiyne have been developed for various fields [23-28], their simple chemistry limits their use. However, MXenes with complex, layered structures that contain at least two elements may offer new properties because they provide numerous compositional var-

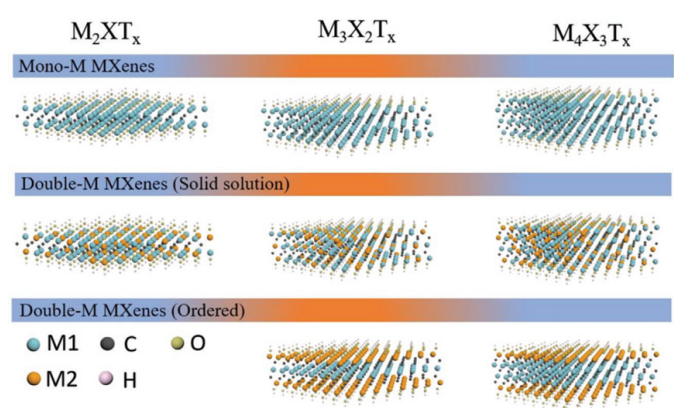

Fig. 1. Typical structures of MXenes $\left(M_{2} X T_{x}, M_{3} X_{2} T_{x}\right.$, and $\left.M_{4} X_{3} T_{x}\right)$ and compositions (mono-M MXenes and double-M MXenes), where $\mathrm{M}$ is an early transition metal and $X$ is $\mathrm{C}$ and/or $\mathrm{N}$ (with the $\mathrm{C}$ element as an example) [21]. iables that can be fine-tuned to achieve specific properties $[22,29]$. Owing to their conductivity, unique structure, and adjustable band structure, MXenes have been considered to be valuable materials for various applications, for instance, energy storage [30-34], biosensors [35,36], and catalysis [21,37,38].

Although MXenes have immense potential in the domain of photocatalysis, they cannot be directly used as photocatalysts because they are essentially not semiconductors [39]. Computational studies have predicted that some $\mathrm{M}_{n+1} \mathrm{X}_{n} \mathrm{~T}_{x}$ carbides/nitrides can be used as semiconductors by altering their surface functional groups. Unfortunately, those have not been experimentally synthesized [40]. Most studies show that MXenes have been successfully developed as co-catalysts for the multiplication of photocatalytic behavior [41-45]. A majority of the recently published review papers on MXenes mainly focused on synthesis, properties, and potential applications in energy-related fields [18,20,46-51]. Because few reviews exist on MXenes as co-catalysts for photocatalytic applications, this study aims to offer a critical overview of the latest advancements in using MXene as a co-catalyst in photocatalysis, which includes photocatalytic $\mathrm{H}_{2}$ evolution, photocatalytic $\mathrm{CO}_{2}$ reduction, photocatalytic $\mathrm{N}_{2}$ fixation, and photocatalytic oxidation of organic pollutants. The synthesis and photocatalytic mechanism of MXenes as co-catalysts are also summarized in this review. In the last section, an outlook for future research directions is proposed from the current challenges.

\section{General method for the synthesis of MXenes}

The MXenes reported to date have been obtained by selectively etching the A element from the MAX phase in the presence of hydrofluoric acid (HF) [29], HF-forming etchants (fluorides and $\mathrm{HCl}$ ) [52,53], or molten fluorides $(\mathrm{KF}, \mathrm{NaF}$ or $\mathrm{LiF}$ at $550{ }^{\circ} \mathrm{C}$ ) [54], as shown in the first step in Fig. 2. This process can be realized because HF-based etchants have high selectivity and can break metallic M-A bonds, which are more fragile than M-X bonds. To obtain mono- or fewer-layered MXenes, the multilayered MXenes are peeled by manual or mechanical agitation (final step in Fig. 2). In addition, an intercalation stage can be optionally used for enhanced MXene exfoliation, and some substances, such as dimethyl sulfoxide [55], tetrabutylammonium hydroxide [56], $\mathrm{NH}_{4} \mathrm{HF}_{2}$ [57], and urea [58], have been verified as effective intercalators.

HF-mediated wet etching is the most frequently used method to synthesize MXenes. Naguib et al. [29] pioneered the etching of the parent $\mathrm{Ti}_{3} \mathrm{AlC}_{2}$ (MAX) with a HF solution, and multilayered MXenes were successfully exfoliated via ultrasonication in a methanol solution. Generally, the chemical reactions for the synthesis of $\mathrm{M}_{n+1} \mathrm{X}_{n} \mathrm{~T}_{x}$ (MXene) by HF etching are described as in Eqs. 1-3 [20].

$$
\begin{aligned}
& \mathrm{M}_{n+1} \mathrm{AlX}_{n}+3 \mathrm{HF} \rightarrow \mathrm{M}_{n+1} \mathrm{X}_{n}+\mathrm{AlF}_{3}+1.5 \mathrm{H}_{2} \\
& \mathrm{M}_{n+1} \mathrm{X}_{n}+2 \mathrm{H}_{2} \mathrm{O} \rightarrow \mathrm{M}_{n+1} \mathrm{X}_{n}(\mathrm{OH})_{2}+\mathrm{H}_{2} \\
& \mathrm{M}_{n+1} \mathrm{X}_{n}+2 \mathrm{HF} \rightarrow \mathrm{M}_{n+1} \mathrm{X}_{n} \mathrm{~F}_{2}+\mathrm{H}_{2}
\end{aligned}
$$

The Al layer in the MAX phase can react with $\mathrm{HF}$ to generate $\mathrm{AlF}_{3}$ and $\mathrm{H}_{2}$ gas, resulting in the exfoliation of the MXene layer (Eq. 1). Furthermore, the multilayered MXene is formed with 0 , $\mathrm{OH}, \mathrm{F}$ terminations, or more likely, a combination of all species 


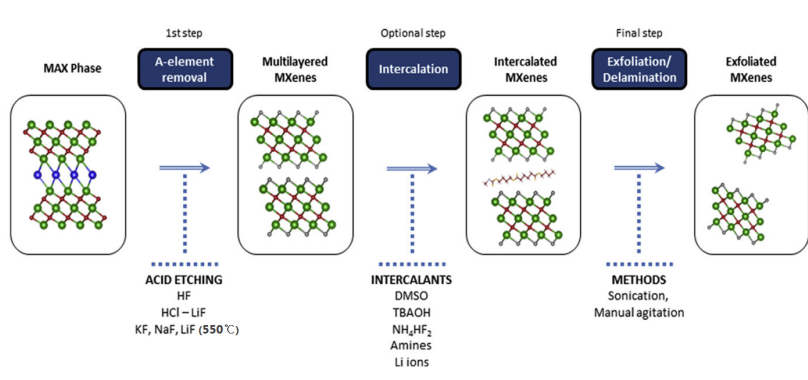

Fig. 2. Schematic diagram illustrating the synthesis of MXenes [51].

(Eq. 2 and Eq. 3). As surface terminations can affect the physicochemical properties of MXenes, it is especially important to elucidate their functions [37]. To avoid the use of toxic and concentrated HF solutions, Ghidiu et al. [52] revealed a safer and high-yield route of $\mathrm{Ti}_{3} \mathrm{C}_{2} \mathrm{~T}_{x}$ (MXene) synthesis by etching $\mathrm{Ti}_{3} \mathrm{AlC}_{2}$ (MAX) with the mixed solution of $\mathrm{LiF}$ and $\mathrm{HCl}$. The etching conditions, such as the $\mathrm{LiF}$ and $\mathrm{HCl}$ content, have certain impacts on the quality of MXene. For example, Shahzad et al. [59] developed a minimally intensive layer delamination (MILD) method to isolate the larger single $\mathrm{Ti}_{3} \mathrm{C}_{2} \mathrm{~T}_{x}$ flakes by fine-tuning the content of $\mathrm{LiF}$ and $\mathrm{HCl}$. This method is conducive to cation intercalation in the etching process, where manual shaking (no sonication) was used and resulted in larger and less defective single flakes of MXene [50]. In general, different MXene applications require different preparation methods. HF etching is recommended for smaller, more defective flakes. For better conductivity and larger sheets, the MILD method is recommended. Urbankowski et al. [54] first reported the synthesis of nitride MXene $\left(\mathrm{Ti}_{4} \mathrm{~N}_{3}\right)$ by heating $\mathrm{Ti}_{4} \mathrm{AlN}_{3}$ in the presence of molten fluorides (KF, NaF or LiF) at $550{ }^{\circ} \mathrm{C}$. During the heating treatment procedure, some fluorine-containing by-products were generated. Therefore, it is necessary to use $\mathrm{H}_{2} \mathrm{SO}_{4}$ to remove these impurities. Finally, few-layered and monolayered flakes were obtained by adding tetrabutylammonium hydroxide under ultrasonic conditions. This molten fluoride salt method is a breakthrough in the preparation of MXenes.

\section{Synthesis of hybridized photocatalysts with MXenes as co-catalysts}

Growing attention has been paid to the intellectual engineering and synthesis of MXenes as co-catalysts in photocatalytic applications, achieving desirable results. Consequently, it is of immense importance to summarize the synthesis method of MXenes as photocatalytic co-catalysts. At present, there are three main synthesis methods: mechanical mixing, self-assembly, and in-situ oxidation.

\subsection{Mechanical mixing}

Mechanical mixing is a relatively simple method for synthesizing composite catalysts; this method has the advantages of saving energy, a low cost, and convenience. The processes of grinding of the solid powders and mixing of the substances in solution were both used to deposit MXenes on the surface of the photocatalysts. According to Sun et al. [60], $\mathrm{Ti}_{3} \mathrm{C}_{2}$ was successfully deposited on the surface of a $\mathrm{g}-\mathrm{C}_{3} \mathrm{~N}_{4}$ photocatalyst via simple mechanical grinding of the mixed g- $\mathrm{C}_{3} \mathrm{~N}_{4}$ and $\mathrm{Ti}_{3} \mathrm{C}_{2}$ (MXene) powders, and the calcined $\mathrm{g}_{-} \mathrm{C}_{3} \mathrm{~N}_{4} / \mathrm{Ti}_{3} \mathrm{C}_{2} \mathrm{~T}_{X}$ composite exhibited improved carrier separation efficiency and enhanced photocatalytic $\mathrm{H}_{2}$ production performance. Ye et al. [61] demonstrated that $\mathrm{Ti}_{3} \mathrm{C}_{2}$ with surficial alkalinization can memorably improve the performance of P25 for photocatalytic $\mathrm{CO}_{2}$ reduction, where the $\mathrm{Ti}_{3} \mathrm{C}_{2}-\mathrm{OH}$ and $\mathrm{P} 25$ were mixed in water by magnetic stirring. Such excellent photocatalytic performance is attributed to the superior conductivity, $\mathrm{CO}_{2}$ adsorption, and activation potential of $\mathrm{Ti}_{3} \mathrm{C}_{2}-\mathrm{OH}$.

\subsection{Self-assembly}

Compared to the composites obtained by the mechanical mixing method, the samples obtained by self-assembly have more intimate contact and more uniform dispersion. Su et al. [3] prepared 2D/2D patterned $\mathrm{Ti}_{3} \mathrm{C}_{2} / \mathrm{g}-\mathrm{C}_{3} \mathrm{~N}_{4}$ hybrids by electrostatic self-assembly and manifested 2D MXene as an efficient co-catalyst for photocatalytic reactions. Because the protonated g- $\mathrm{C}_{3} \mathrm{~N}_{4}$ is positively charged and the MXene surface is negatively charged, the electrostatic induced sticking (self-assembly) between $\mathrm{Ti}_{3} \mathrm{C}_{2}$ and $\mathrm{g}-\mathrm{C}_{3} \mathrm{~N}_{4}$ causes the formation of a $\mathrm{Ti}_{3} \mathrm{C}_{2} / g-\mathrm{C}_{3} \mathrm{~N}_{4}$ 2D/2D patterned heterojunction. Similarly, $\mathrm{Ag}_{3} \mathrm{PO}_{4} / \mathrm{Ti}_{3} \mathrm{C}_{2}$ [41], $\mathrm{TiO}_{2}$ nanofibers/ $\mathrm{Ti}_{3} \mathrm{C}_{2}$ [62], CdS/ $\mathrm{Ti}_{3} \mathrm{C}_{2} \mathrm{~T}_{x}$ [63], and a series of MXene-based composite photocatalysts can be synthesized by this method.

\subsection{In-situ oxidation}

In contrast with the above methods, a hybridized photocatalyst containing MXene can be obtained by direct in-situ oxidation of MXenes. As the formed metal oxide (MO) is chemically bonded with MXenes, the strong and intimate contact endows the hybrid with unique optical and electronic properties. Peng et al. [64] synthesized a compound of $\mathrm{Ti}_{3} \mathrm{C}_{2}$ and $\mathrm{TiO}_{2}$ uncovering $\{001\}$ facets via a partially hydrothermal oxidation of $\mathrm{Ti}_{3} \mathrm{C}_{2}$. Su et al. [45] prepared $\mathrm{Nb}_{2} \mathrm{O}_{5} / \mathrm{C} / \mathrm{Nb}_{2} \mathrm{C}$ nanocomposites via single-step $\mathrm{CO}_{2}$ oxidation of $\mathrm{Nb}_{2} \mathrm{CT}_{x}$. They found that the oxidation time of $\mathrm{Nb}_{2} \mathrm{CT}_{x}$ plays an important role in the optical and photocatalytic properties of the $\mathrm{Nb}_{2} \mathrm{O}_{5} / \mathrm{C} / \mathrm{Nb}_{2} \mathrm{C}$ hybrid, and the sample with an oxidation time of $1 \mathrm{~h}$ has the highest hydrogen evolution rate (HER), which is four fold higher than that of pure $\mathrm{Nb}_{2} \mathrm{O}_{5}$. The products of MXene oxidation by this method are generally MO/MXene or MO/MXene/C (mostly amorphous carbon), in which $\mathrm{C}$ and MXene can be used as co-catalysts in photocatalytic reactions [39]. However, this method can only be used when the MO is a semiconductor.

\section{Photocatalytic mechanism for MXenes as co-catalysts}

For most semiconductor photocatalysts, the photo-generated carriers could rapidly recombine to release heat and luminous energy, leading to a low photocatalysis performance [65-69]. Loading co-catalysts is considered an available tactic to advance the performance and efficiency of photocata- 
lysts (Fig. 3). Coupling MXenes with semiconductor photocatalysts is beneficial in the application of photocatalysis because the 2D layered substrate of MXenes can provide abundant adsorption sites and strong metal conductivity [61,70]. It has been well documented that MXene-based nanocomposites exhibit better stability and reproducibility $[13,71]$.

Because of the different Fermi energy levels of MXenes and the host catalysts, the photo-aroused electrons will migrate from the conduction band (CB) of the main catalyst to the MXenes with strong conductivity [72]. With the accumulation of negative photo-generated electrons on the MXenes, the $\mathrm{CB}$ and valence band (VB) of the main catalyst will bend upward, forming a Schottky barrier. In addition, the Schottky barrier will impede the electron transfer back to the main catalyst from the MXenes and promote the fast shuttle of electrons [13]. The electrons accumulated on MXenes can react with $\mathrm{H}^{+}$to produce hydrogen or reduce $\mathrm{CO}_{2}$ to $\mathrm{CH}_{4}, \mathrm{CO}, \mathrm{CH}_{3} \mathrm{OH}$, etc.; likewise, the holes can be used for decontaminating the organic pollutants [73].

The Schottky barrier between the MXenes and the main catalyst can inhibit the recombination of photo-generated carriers and promote the process of photocatalysis. Of course, the interface between the main catalyst and MXenes needs strong and intimate contact, which has a synergistic effect with the Schottky section to improve the photocatalytic efficiency.

\section{Application of MXene-based composites in photocatalysis}

\subsection{Photocatalytic hydrogen evolution}

The development of sustainable society requires progress toward clean technology and likewise triggers the enthusiasm of researchers for renewable energy exploration [25,74,75]. $\mathrm{H}_{2}$, which has a high energy density of $140 \mathrm{MJ} \mathrm{kg}^{-1}$, produces only water during combustion; thus, it is considered to be the cleanest product that can meet future fuel demands [76-80]. $\mathrm{H}_{2}$ production driven by sunlight can function as an intriguing strategy to eliminate energy crises and environmental problems. However, large-scale solar $\mathrm{H}_{2}$ production requires efficient and stable co-catalysts. Recently, MXene has emerged as a co-catalyst in the field of photocatalysis. MXene can work as an ambitious and cost-effective alternative to $\mathrm{H}_{2}$ production that uses noble metal co-catalysts.

In 2016, Ran et al. [81] fabricated a composite material consisting of $\mathrm{Ti}_{3} \mathrm{C}_{2}$ nanoparticles and $\mathrm{CdS}$ with preeminent reactivity, which can act as one kind of noble-metal-free photocatalyst

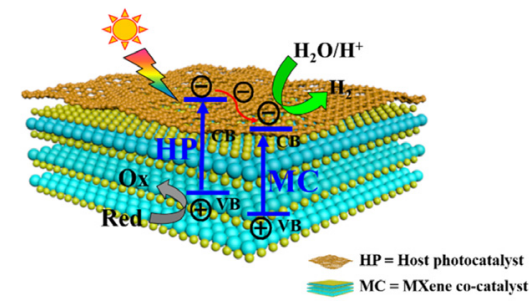

Fig. 3. Scheme illustrating the photocatalytic mechanism of MXene-based photocatalysts [73]. for visible-light-motivated $\mathrm{H}_{2}$ generation. The $\mathrm{CdS} / \mathrm{Ti}_{3} \mathrm{C}_{2}$ composite photocatalyst (Fig. $4 \mathrm{~A}$ and $4 \mathrm{~B}$ ) was prepared using a hydrothermal strategy. Through optimization of the loading amount of $\mathrm{Ti}_{3} \mathrm{C}_{2}$ co-catalyst, the $2.5 \mathrm{wt} \% \mathrm{CdS} / \mathrm{Ti}_{3} \mathrm{C}_{2}$ composite showed the highest photocatalytic $\mathrm{H}_{2}$ evolution rate $(14,342$ $\mu \mathrm{mol} \mathrm{h} \mathrm{h}^{-1} \mathrm{~g}^{-1}$ ). It had an apparent quantum efficiency (AQE) of $40.1 \% @ 420 \mathrm{~nm}$ when lactic acid was used as the sacrificial reagent, identifying the noble-metal-free metal-sulfide photocatalyst with the highest activity (Fig. 4C). The highly efficient separation of electron-hole pairs and the rapid $\mathrm{H}_{2}$ production on the abundant -0 terminations presenting on $\mathrm{Ti}_{3} \mathrm{C}_{2}$ nanoparticles (NPs) is the reason for the distinctive photocatalytic behavior of $\mathrm{CdS} / \mathrm{Ti}_{3} \mathrm{C}_{2}$. This study indicated that MXenes can serve as alternatives to precious metals in solar water splitting.

Despite MXene being an effective co-catalyst for $\mathrm{H}_{2}$ evolution, the co-catalytic performance is restrained by weak contact with the main catalyst. Recently, Yang et al. [82] showed that the physical interaction between CdS NPs and layered $\mathrm{Ti}_{3} \mathrm{C}_{2} \mathrm{~T}_{x}$ can be strengthened by $\mathrm{O}_{2}-\mathrm{N}_{2}$-plasma treating $\mathrm{Ti}_{3} \mathrm{C}_{2} \mathrm{~T}_{x}$. They successfully prepared plasma-modified $\mathrm{Ti}_{3} \mathrm{C}_{2} \mathrm{~T}_{x} / \mathrm{CdS}$ hybrids via a mild solvothermal method. By optimizing the content of $\mathrm{Ti}_{3} \mathrm{C}_{2} \mathrm{~T}_{x} / \mathrm{CdS}$ of $1.0 \mathrm{wt} \%$, the highest $\mathrm{H}_{2}$-production rate $(825$ $\mu \mathrm{mol} \mathrm{h}^{-1} \mathrm{~g}^{-1}$ ) was achieved using visible light alongside lactic acid as sacrificial reagent, which had an AQE of $10.2 \%$ @ 450 nm. As described in Figs. 4D-E, the CB potential of CdS NPs is more negative than the $\mathrm{E}_{\mathrm{f}}$ of $\mathrm{Ti}_{3} \mathrm{C}_{2} \mathrm{~T}_{x}$, which enabled the electrons to migrate from $\mathrm{CdS}$ to $\mathrm{Ti}_{3} \mathrm{C}_{2} \mathrm{~T}_{x}$.

Generally, the excellent $\mathrm{H}_{2}$ evolution performance could be attributed to the oxygen-containing group on the $\mathrm{Ti}_{3} \mathrm{C}_{2} \mathrm{~T}_{x}$ surface and the intimate contact between CdS NPs and $\mathrm{Ti}_{3} \mathrm{C}_{2}$. The former is good for capturing $\mathrm{H}_{2} \mathrm{O} / \mathrm{H}^{+}$, while the latter is feasible for inhibiting the electron-hole recombination. Some metal sulfides undergo easy photo-corrosion during the photocatalytic reaction; therefore, it is significant to improve the stability of these metal sulfide photocatalysts. Xu et al. [63] provided a new mechanistic insight into $\mathrm{Ti}_{3} \mathrm{C}_{2} \mathrm{~T}_{x}$ in-situ confine $\mathrm{Cd}^{2+}$ ions to avoid their leaching and achieved desirable results.

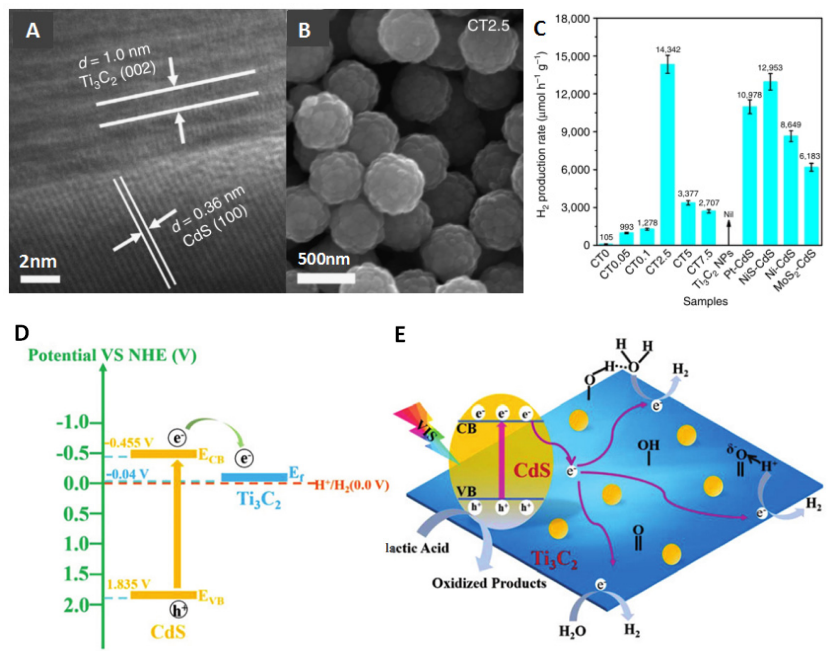

Fig. 4. HRTEM (A) and SEM (B) images of $\mathrm{CdS} / \mathrm{Ti}_{3} \mathrm{C}_{2}$ composite (CT2.5). Comparison of the photocatalytic $\mathrm{H}_{2}$ production rate (C) [81], the band structure (D), and the proposed photocatalytic mechanism of $\mathrm{CdS} / \mathrm{Ti}_{3} \mathrm{C}_{2} \mathrm{~T}_{x}(\mathrm{E})[82]$. 
Although the HER performance of CdS can be greatly improved via employing MXene as a co-catalyst; $\mathrm{Cd}$ is an environmentally hostile contaminant. Wang et al. [13] prepared some titania composites with 2D transition metal carbides through a hydrothermal method. Through optimization of the content of a $\mathrm{TiO}_{2} / \mathrm{Ti}_{3} \mathrm{C}_{2} \mathrm{~T}_{x}$ composite, a fourfold enhancement could be achieved in the photocatalytic HER with $5 \mathrm{wt} \% \mathrm{Ti}_{3} \mathrm{C}_{2} \mathrm{~T}_{x}$ as co-catalyst compared to that of pure rutile $\mathrm{TiO}_{2}$ (Fig. 5A). They likewise offered a deeper understanding of the mechanism of other MXenes $\left(\mathrm{Nb}_{2} \mathrm{CT}_{x}\right.$ and $\left.\mathrm{Ti}_{2} \mathrm{CT}_{x}\right)$ as co-catalysts with $\mathrm{TiO}_{2}$. Those photocatalysts also showed increased photocatalytic $\mathrm{H}_{2}$ evolution activity because photo-excited electrons can transfer to metal carbides $\left(\mathrm{M}_{x} \mathrm{C}_{y}\right)$ from $\mathrm{CB}$, and the formed Schottky barrier between metal carbides and $\mathrm{TiO}_{2}$ can impede electrons from returning to semiconductor species (Fig. 5B). The study suggested that MXenes be used as an effective co-catalyst to support $\mathrm{TiO}_{2}$ for solar $\mathrm{H}_{2}$ generation.

It is well known that the intimate contact between a co-catalyst and the main catalyst is of immense importance, as it can provide more highways for photo-generated electron transfer. Using F-termination $\mathrm{Ti}_{3} \mathrm{C}_{2}$ as a precursor, Xiang et al. [83] reported the fabrication of $\mathrm{TiO}_{2}$ by in-situ growth on MXene, where the remaining $\mathrm{Ti}_{3} \mathrm{C}_{2}$ could be employed as a co-catalyst to promote photocatalytic activity by capturing photo-generated electrons from $\mathrm{TiO}_{2}$ because of the sinking nature of its electrons and the suitable Fermi level. Furthermore, Tian et al. [84] synthesized a 2D/2D/2D heterojunction of a $\mathrm{Ti}_{3} \mathrm{C}_{2}$ MXene/MoS 2 nanosheet/ $\mathrm{TiO}_{2}$ nanosheet through a two-step hydrothermal method (Fig. 5C) for water splitting to
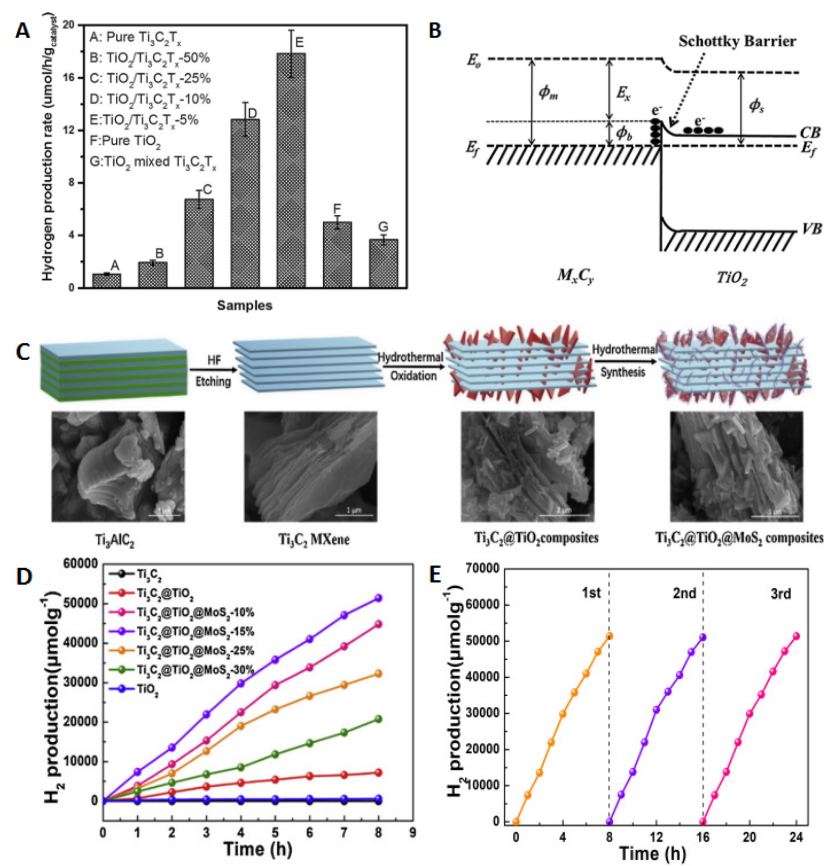

Fig. 5. Effect of $\mathrm{Ti}_{3} \mathrm{C}_{2} \mathrm{~T}_{x}$ loading amount on photocatalytic $\mathrm{H}_{2}$ production over $\mathrm{TiO}_{2} / \mathrm{Ti}_{3} \mathrm{C}_{2} \mathrm{~T}_{x}$ composites (A), the formation of Schottky barrier at the MXene/ $\mathrm{TiO}_{2}$ interface (B) [13], schematic illustration of the preparation of $\mathrm{Ti}_{3} \mathrm{C}_{2} @ \mathrm{TiO}_{2} @ \mathrm{MoS}_{2}$ composites (C), effect of $\mathrm{MoS}_{2}$ loading amount on the photocatalytic $\mathrm{H}_{2}$ production of $\mathrm{Ti}_{3} \mathrm{C}_{2} @ \mathrm{TiO}_{2} @ \mathrm{MoS}_{2}$ hybridized photocatalyst (D), and the recyclability of the $\mathrm{Ti}_{3} \mathrm{C}_{2} @ \mathrm{TiO}_{2} @ \mathrm{MoS}_{2}-15 \%$ photocatalyst (E) [84]. produce $\mathrm{H}_{2}$, and the heterojunction showed remarkable enhancement and excellent stability in photocatalytic reactions (Fig. 5D and Fig. 5E). The reason for the improvement of photocatalytic $\mathrm{H}_{2}$ production ability is that the $\mathrm{TiO}_{2}$ nanosheet grows on MXene in situ, which is more favorable for electron transport. Simultaneously, the dual co-catalysts also promoted the separation of photo-generated carriers to some extent.

As a polymeric semiconductor photocatalyst, graphitic carbon nitride $\left(\mathrm{g}-\mathrm{C}_{3} \mathrm{~N}_{4}\right)$ with a bandgap of $2.7 \mathrm{eV}$ exhibits photocatalytic $\mathrm{H}_{2}$ generation performance with the irradiation of visible light [60,77]. In 2017, Shao et al. [85] reported an innovative material containing $2 \mathrm{D} \mathrm{Ti}_{2} \mathrm{C}$ MXene and g- $\mathrm{C}_{3} \mathrm{~N}_{4}$, and it was found that a $0.4 \mathrm{wt} \% \mathrm{Ti}_{2} \mathrm{C} / \mathrm{g}-\mathrm{C}_{3} \mathrm{~N}_{4}$ heterostructure composite possessed the highest $\mathrm{H}_{2}$ evolution rate $\left(47.5 \mu \mathrm{mol} \mathrm{h}{ }^{-1}\right)$, which is 14.4 fold higher than that of individual $\mathrm{g}-\mathrm{C}_{3} \mathrm{~N}_{4}$ and even transcends Pt-loading $\mathrm{g}-\mathrm{C}_{3} \mathrm{~N}_{4}$. In addition, the prepared $\mathrm{Ti}_{2} \mathrm{C} / \mathrm{g}-\mathrm{C}_{3} \mathrm{~N}_{4}$ exerts good durability and repeatability. The excellent performance can be ascribed to the intimate combination of $\mathrm{g}-\mathrm{C}_{3} \mathrm{~N}_{4}$ and $\mathrm{Ti}_{2} \mathrm{C}$ MXene, which accelerated the photo-induced carrier segregation and delivery to metallic $\mathrm{Ti}_{2} \mathrm{C}$, leading to charge accumulation. Afterward, these accumulated electrons cause the negative shift of Fermi energy level that is beneficial to $\mathrm{H}_{2}$ production (Fig. 6A). Similar findings were also reported by $\mathrm{Su}$ et al. [3] in further research on 2D/2D $\mathrm{Ti}_{3} \mathrm{C}_{2} / \mathrm{g}-\mathrm{C}_{3} \mathrm{~N}_{4}$ hybrids, in which the optimized $\mathrm{Ti}_{3} \mathrm{C}_{2} / \mathrm{g}-\mathrm{C}_{3} \mathrm{~N}_{4}$ photocatalyst exhibited a 10 fold higher HER performance $\left(72.3 \mu \mathrm{mol} \mathrm{h}{ }^{-1} \mathrm{~g}^{-1}\right)$ than that of pure $\mathrm{g}-\mathrm{C}_{3} \mathrm{~N}_{4}$.

Recently, Tian et al. [86] obtained g- $\mathrm{C}_{3} \mathrm{~N}_{4} @ \mathrm{Ti}_{3} \mathrm{C}_{2}$ MXene quantum dots (QDs) using a self-assembly method. The $\mathrm{Ti}_{3} \mathrm{C}_{2}$ MXene QDs showed better performance than $\mathrm{Pt}$ as a co-catalyst in elevating the photocatalytic HER with a $\mathrm{g}-\mathrm{C}_{3} \mathrm{~N}_{4}$ nanosheet (Fig. 6B and Fig. 6C). The results of the study demonstrated that low-dimensional MXenes material can be employed to enlarge the specific surface area and afford more active sites.

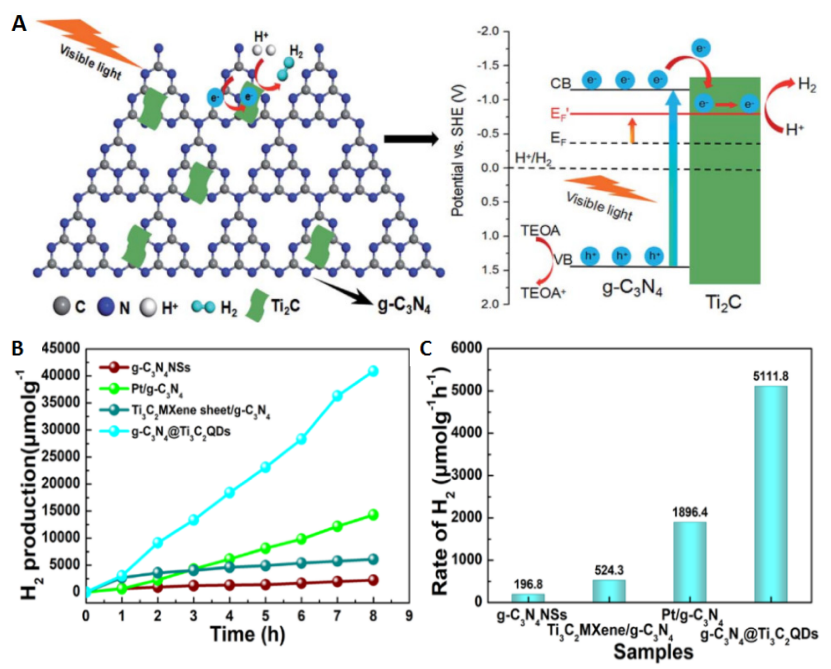

Fig. 6. The mechanism of photocatalytic $\mathrm{H}_{2}$ evolution on $\mathrm{Ti}_{2} \mathrm{C} / \mathrm{g}-\mathrm{C}_{3} \mathrm{~N}_{4}, E_{\mathrm{f}}$ and $E_{\mathrm{f}}^{\prime}$ refer to the Fermi levels of $\mathrm{g}-\mathrm{C}_{3} \mathrm{~N}_{4}$ before and after attaining equilibrium, severally (A) [85], the photocatalytic $\mathrm{H}_{2}$ production curves (B), and the corresponding $\mathrm{H}_{2}$ evolution rate (C) [86]. 
Table 1

Summary of the photocatalytic $\mathrm{CO}_{2}$ reduction over MXene-based photocatalysts.

\begin{tabular}{|c|c|c|c|c|c|c|}
\hline Catalyst & Weight (mg) & MXene & Light Source & System & Production & Ref. \\
\hline $\mathrm{TiO}_{2} / \mathrm{Ti}_{3} \mathrm{C}_{2}$ & 50 & $\mathrm{Ti}_{3} \mathrm{C}_{2}$ & Xe lamp $(300 \mathrm{~W})$ & $\begin{array}{l}\mathrm{CO}_{2} \text { in-situ generated by } \mathrm{NaHCO}_{3} \\
\text { and } \mathrm{HCl}(200 \mathrm{ml} \text { Pyrex reactor) }\end{array}$ & $4.4 \mu \mathrm{mol} / \mathrm{g} / \mathrm{h}\left(\mathrm{CH}_{4}\right)$ & [91] \\
\hline $\mathrm{Bi}_{2} \mathrm{WO}_{6} / \mathrm{Ti}_{3} \mathrm{C}_{2}$ & 100 & $2 \mathrm{wt} \% \mathrm{Ti}_{3} \mathrm{C}_{2}$ & Xe lamp & $\begin{array}{l}\mathrm{CO}_{2} \text { in-situ generated by } \mathrm{NaHCO}_{3} \\
\text { and } \mathrm{H}_{2} \mathrm{SO}_{4}(200 \mathrm{ml} \text { Pyrex reactor })\end{array}$ & $\begin{array}{c}1.78 \mu \mathrm{mol} / \mathrm{g} / \mathrm{h}\left(\mathrm{CH}_{4}\right) \\
0.44 \mu \mathrm{mol} / \mathrm{g} / \mathrm{h}\left(\mathrm{CH}_{3} \mathrm{OH}\right)\end{array}$ & [43] \\
\hline $\mathrm{TiO}_{2}(\mathrm{P} 25) / \mathrm{Ti}_{3} \mathrm{C}_{2}-\mathrm{OH}$ & 50 & $5 \mathrm{wt} \% \mathrm{Ti}_{3} \mathrm{C}_{2}-\mathrm{OH}$ & Xe lamp $(300 \mathrm{~W})$ & $\begin{array}{l}\text { Closed circulation system } \\
\left(70 \mathrm{kPa} \text { of } \mathrm{CO}_{2}\right)\end{array}$ & $\begin{array}{l}16.61 \mu \mathrm{mol} / \mathrm{g} / \mathrm{h}\left(\mathrm{CH}_{4}\right) \\
11.74 \mu \mathrm{mol} / \mathrm{g} / \mathrm{h}(\mathrm{CO})\end{array}$ & [61] \\
\hline $\mathrm{CeO}_{2} / \mathrm{Ti}_{3} \mathrm{C}_{2}$ & 50 & $5 \mathrm{wt} \% \mathrm{Ti}_{3} \mathrm{C}_{2}$ & Xe lamp & $\begin{array}{l}\mathrm{CO}_{2} \text { in-situ generated by } \mathrm{NaHCO}_{3} \\
\text { and } \mathrm{HCl}(200 \mathrm{ml} \text { Pyrex reactor })\end{array}$ & $26.1 \mu \mathrm{mol} / \mathrm{m}^{2} / \mathrm{h}(\mathrm{CO})$ & [72] \\
\hline $\mathrm{Ti}_{3} \mathrm{C}_{2} \mathrm{QDs} / \mathrm{Cu}_{2} \mathrm{O} / \mathrm{Cu}$ & - & $\mathrm{Ti}_{3} \mathrm{C}_{2} \mathrm{QDs}$ & Xe lamp $(300 \mathrm{~W})$ & $\begin{array}{l}\text { High purity } \mathrm{CO}_{2} \text { gas ( } 100 \mathrm{ml} \text { quartz } \\
\text { bottle) }\end{array}$ & $153.38 \mathrm{ppm} / \mathrm{cm}^{2}\left(\mathrm{CH}_{3} \mathrm{OH}\right)$ & [42] \\
\hline $\mathrm{CsPbBr}_{3} / \mathrm{MXene}$ & - & $\mathrm{Ti}_{3} \mathrm{C}_{2} \mathrm{NSs}$ & $\begin{array}{c}\text { Xe-lamp } \\
(300 \mathrm{~W}, \lambda>420 \mathrm{~nm})\end{array}$ & Photocatalyst in ethyl acetate & $\begin{array}{l}14.64 \mu \mathrm{mol} / \mathrm{g} / \mathrm{h}\left(\mathrm{CH}_{4}\right) \\
32.15 \mu \mathrm{mol} / \mathrm{g} / \mathrm{h}(\mathrm{CO})\end{array}$ & [92] \\
\hline
\end{tabular}

\subsection{Photocatalytic $\mathrm{CO}_{2}$ reduction}

With the development of human industrialization, the consumption of fossil energy produces considerable $\mathrm{CO}_{2}$, which increases the greenhouse effect $[87,88]$. Conversion of $\mathrm{CO}_{2}$ into high value-added fuels has become a major scientific challenge, because it can solve both the energy problem and the environmental crisis. Although $\mathrm{CO}_{2}$ is an essential element of $\mathrm{C} 1$ in the chemical industry, its stable molecular structure hinders its application in industrial production. Photocatalytic $\mathrm{CO}_{2}$ reduction (artificial photosynthesis) has been considered as an ideal way to solve this challenge and obtain clean fuel using solar light. Recent studies show that MXene can also perform as an attractive co-catalyst for photocatalytic $\mathrm{CO}_{2}$ reduction (Table 1).

Ye et al. [61] attested the distinctly enhanced performance of $\mathrm{P} 25$ in $\mathrm{CO}_{2}$ photo-reduction by exploiting $\mathrm{Ti}_{3} \mathrm{C}_{2}$ MXene as a precious-metal-free co-catalyst. The introduction of $\mathrm{Ti}_{3} \mathrm{C}_{2}-\mathrm{OH}$ (surface alkalinization) with P25 could dramatically enhance the photocatalytic $\mathrm{CO}_{2} \mathrm{RR}$ with the production rate of $\mathrm{CO}(11.74$ $\left.\mu \mathrm{mol} \mathrm{h}-1 \mathrm{~g}^{-1}\right)$ and $\mathrm{CH}_{4}\left(16.61 \mu \mathrm{mol} \mathrm{h}^{-1} \mathrm{~g}^{-1}\right)$, which are approximately 3 and 277 fold higher, respectively, than those of pure P25 (Fig. 7A). According to the density functional theory (DFT) results (Fig. 7B), the adsorption energy of $\mathrm{CO}_{2}$ on $\mathrm{Ti}_{3} \mathrm{C}_{2}-\mathrm{F}$ was $-0.13 \mathrm{eV}$, which is much higher than that of $\mathrm{CO}_{2}$ on $\mathrm{Ti}_{3} \mathrm{C}_{2}-\mathrm{OH}$ $(-0.44 \mathrm{eV})$. Therefore, $\mathrm{CO}_{2}$ could be adsorbed on $\mathrm{Ti}_{3} \mathrm{C}_{2}-\mathrm{OH}$ more easily than $\mathrm{Ti}_{3} \mathrm{C}_{2}-\mathrm{F}$. This study suggested that the superior conductivity and $\mathrm{CO}_{2}$ adsorption and activation capacity of $\mathrm{Ti}_{3} \mathrm{C}_{2}-\mathrm{OH}$ contributed to the enhancement of photocatalytic $\mathrm{CO}_{2}$ reduction. Compared to other carbon-based materials such as graphene and graphdiyne [89,90], MXene-based compounds exhibit superior selectivity in photocatalytic $\mathrm{CO}_{2}$ reduction to $\mathrm{CH}_{4}[61,91]$.

Decreasing the size and the number of layers of MXene is conducive to reducing the carrier transfer distance and providing a large interface contact area. Cao et al. [43] successfully prepared a novel 2D/2D heterojunction of ultrathin $\mathrm{Ti}_{3} \mathrm{C}_{2}$ MXene/BiWO 6 nanosheets (Fig. 7C-E), and they found that a 5 wt $\% \mathrm{Ti}_{3} \mathrm{C}_{2} / \mathrm{BiWO}_{6}$ hybrid presented the highest $\mathrm{CO}_{2}$ photo-reduction reactivity in general and had a total yield of $\mathrm{CH}_{4}$ and $\mathrm{CH}_{3} \mathrm{OH}$ that was 4.6 fold higher than that prepared on pure $\mathrm{Bi}_{2} \mathrm{WO}_{6}$ ultrathin nanosheets. This work not only presented a novel 2D/2D heterojunction photocatalyst but also proved that $\mathrm{Ti}_{3} \mathrm{C}_{2}$ can qualify as a high-efficiency co-catalyst in the photocatalytic reduction of $\mathrm{CO}_{2}$. Furthermore, Chen et al. [42] expanded the dimension of MXene materials to zero and coupled it with $1 \mathrm{D} \mathrm{Cu}_{2} \mathrm{O}$ nanowires on $\mathrm{Cu}$ mesh through a facile self-assembly method. The methanol production from the photocatalytic $\mathrm{CO}_{2} \mathrm{RR}$ from $\mathrm{Ti}_{3} \mathrm{C}_{2}$ QDs/ $\mathrm{Cu}_{2} \mathrm{O}$ nanowires (NWs)/Cu heterojunction was 8.25 and 2.15 fold higher than that of $\mathrm{Cu}_{2} \mathrm{O}$ $\mathrm{NWs} / \mathrm{Cu}$ and $\mathrm{Ti}_{3} \mathrm{C}_{2}$ nanosheets $/ \mathrm{Cu}_{2} \mathrm{O}$ NWs/Cu, respectively
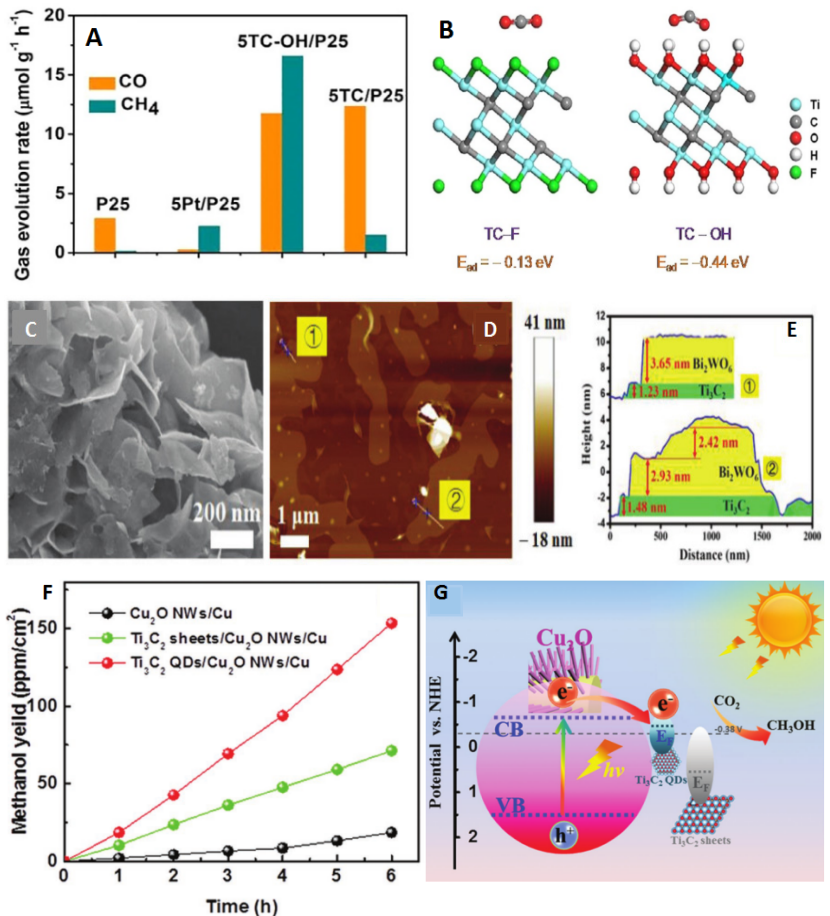

Fig. 7. Comparison of the gas evolution rates of $\mathrm{CO}$ and $\mathrm{CH}_{4}$ over $\mathrm{P} 25$, 5Pt/P25, 5 wt\% $\mathrm{Ti}_{3} \mathrm{C}_{2}-\mathrm{OH} / \mathrm{P} 25$, and 5 wt $\% \mathrm{Ti}_{3} \mathrm{C}_{2} @ \mathrm{OH} / \mathrm{P} 25$ under Xe lamp irradiation (A); side view of the adsorption models of $\mathrm{CO}_{2}$ on $2 * 2 * 1 \mathrm{Ti}_{3} \mathrm{C}_{2}-\mathrm{F}$ and $2 * 2 * 1 \mathrm{Ti}_{3} \mathrm{C}_{2}-\mathrm{OH}$ supercells (B) [61]; FESEM (C); AFM (D) images and height cutaway view (E) of ultrathin $\mathrm{Ti}_{3} \mathrm{C}_{2}$ MXene $/ \mathrm{Bi}_{2} \mathrm{WO}_{6}$ [43]; evolution rate of methanol as a function of irradiation time (F); and the proposed energy level diagram of $\mathrm{Ti}_{3} \mathrm{C}_{2} \mathrm{QDs} / \mathrm{Cu}_{2} \mathrm{O}$ NWs/Cu and $\mathrm{Ti}_{3} \mathrm{C}_{2}$ sheets/Cu2 $\mathrm{O}$ NWs/Cu photocatalysts (G) [42]. 
(Fig. 7F). Based on theoretical and experimental results, the $\mathrm{Ti}_{3} \mathrm{C}_{2}$ QDs can facilitate the activity and stability of $\mathrm{CO}_{2}$ photo-reduction over $\mathrm{Cu}_{2} \mathrm{O}$ nanowires by enhancing electron transport, carrier density, and light absorption, as well as by improving carrier separation. As illustrated in Fig. 7G, under simulated sunlight, photo-motivated electrons transmit from the VB to the $\mathrm{CB}$ of $\mathrm{Cu}_{2} \mathrm{O}$. Because $\mathrm{Ti}_{3} \mathrm{C}_{2}$ QDs have high conductivity and their Fermi energy level is lower than the $\mathrm{CB}$ potential of $\mathrm{Cu}_{2} \mathrm{O}$, photo-generated electrons tend to transfer to $\mathrm{Ti}_{3} \mathrm{C}_{2}$ QDs for accumulation rather than recombination. The Fermi energy level of $\mathrm{Ti}_{3} \mathrm{C}_{2}$ QDs is negative to the redox potential of $\mathrm{CO}_{2}$ to methanol; therefore, the accumulated electrons contribute to the enhancement of $\mathrm{CO}_{2}$ reduction to methanol. Compared to the more positive Fermi energy level of the $\mathrm{Ti}_{3} \mathrm{C}_{2}$ sheet (0.71 V vs $\mathrm{NHE}, \mathrm{pH}=7$ ) [91], $\mathrm{Ti}_{3} \mathrm{C}_{2}$ QDs are more favorable for catalyzing the reaction.

\subsection{Photocatalytic nitrogen fixation}

Nitrogen, the most abundant gas in the atmosphere, plays a crucial role in preserving life on earth. Currently, ammonia $\left(\mathrm{NH}_{3}\right)$ is the necessary raw material for the large-scale production of numerous chemical products, especially fertilizers. Atmospheric $\mathrm{N}_{2}$ is the cornerstone of ammonia synthesis, but it is difficult use because of its stable nonpolar energetic $\mathrm{N} \equiv \mathrm{N}$ triple bond [93]. Undeniably, the Haber-Bosch process is a landmark in the utilization of $\mathrm{N}_{2}$, as it converts atmospheric $\mathrm{N}_{2}$ and $\mathrm{H}_{2}$ into $\mathrm{NH}_{3}$ at a high temperature and pressure [94]. Nevertheless, the traditional synthetic ammonia process requires extremely harsh conditions and causes extensive energy consumption. Therefore, synthesizing $\mathrm{NH}_{3}$ via the photocatalytic reduction of $\mathrm{N}_{2}$ under mild conditions is of great significance. MXene, as a rising co-catalyst, has been used for photocatalytic $\mathrm{N}_{2}$ fixation.

MXene demonstrates excellent performance in photocatalytic $\mathrm{N}_{2}$ fixation. For instance, Qin et al. [95] reported a Z-scheme heterojunction (AgInS 2 /MXene) based on 0D AgInS 2 nanoparticles and 2D MXene $\left(\mathrm{Ti}_{3} \mathrm{C}_{2}\right)$ nanosheets for photocatalytic $\mathrm{N}_{2}$ reduction under ambient conditions. Originating from the unique sheet-structure of $\mathrm{Ti}_{3} \mathrm{C}_{2}$ and formation of a Z-scheme heterojunction, the $\mathrm{AgInS}_{2}$ /MXene heterojunction exhibits excellent interfacial charge transfer properties. The obtained composite with $30 \% \operatorname{AgInS}_{2}$ shows the highest $\mathrm{N}_{2}$ fixation activity with an ammonia yield of $38.8 \mu \mathrm{mol} \mathrm{g}{ }^{-1} \mathrm{~h}^{-1} \mathrm{un}-$ der visible light. DFT simulations were also used to investigate $\mathrm{N}_{2}$ adsorption modes on the surface of $\mathrm{Ti}_{3} \mathrm{C}_{2}(001)$ three different ways (Figs. 8A-C). The optimal adsorption configuration is of $\mathrm{N}_{2}$ in a dinuclear end-on bound structure in which one of the $\mathrm{N}$ atoms binds with a Ti-Ti tripolymer and the other binds with Ti-Ti dimers (Fig. 8C). In this case, the adsorption energy ( $\left.E_{\mathrm{ad}}\right)$ of $\mathrm{N}_{2}$ molecules would be as large as $-5.20 \mathrm{eV}$. Through these advantageous properties, MXene may provide an accessible kinetic pathway for highly efficient $\mathrm{N}_{2}$ fixation. The electron transfer behaviors between $\mathrm{Ti}_{3} \mathrm{C}_{2}$ and $\mathrm{N}_{2}$ were investigated through the charge density difference (Figs. 8D and 8E). As the $d$-orbital electrons on vicinal Ti atom are injected into the absorbed nitrogen molecule, the triple bond of $\mathrm{N}_{2}$ will be weak-
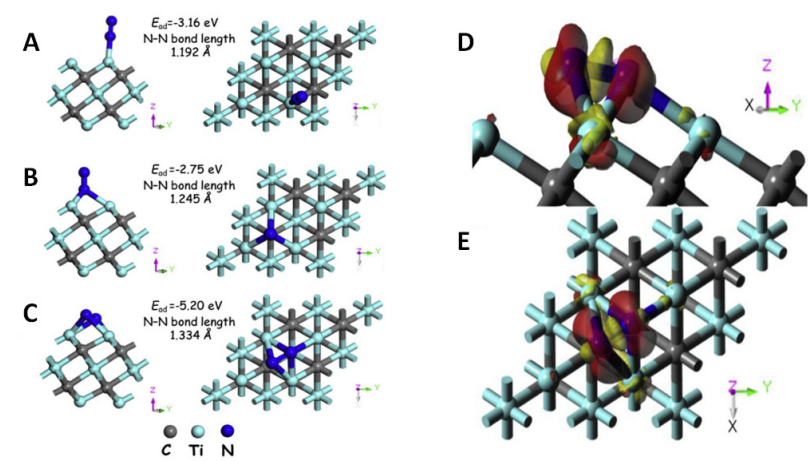

Fig. 8. Three models for the adsorption of $\mathrm{N}_{2}$ molecules on $\mathrm{Ti}_{3} \mathrm{C}_{2}(001)$ surface $(A-C)$. The charge density difference of the $\mathrm{N}_{2}$-adsorbed $\mathrm{Ti}_{3} \mathrm{C}_{2}$ (001) surface: side view (D) and top view (E). The red and yellow isosurfaces represent the charge accumulation and depletion in the space, respectively [95].

ened, to some extent, by an increased bond length (from 1.0975 $\AA$ in free $\mathrm{N}_{2}$ to $1.334 \AA$ ) , which is conducive to the $\mathrm{N}_{2}$ reduction.

Recently, Hao et al. developed a $\mathrm{RuO}_{2}$-loaded $\mathrm{TiO}_{2}$-MXene hybrid via a hydrothermal method for nitrogen photocatalytic fixation [96]. The results suggest that MXene $\left(\mathrm{Ti}_{3} \mathrm{C}_{2}\right)$ with metallic conductivity provides an efficient transport pathway for photo-generated electrons. In addition, molecular $\mathrm{N}_{2}$ can easily adsorb on the surface of MXenes with high exothermic energy. In contrast, Wang et al. [97] reported a new microporous MIL-100( $\mathrm{Fe}) / \mathrm{Ti}_{3} \mathrm{C}_{2}$ MXene composite with enhanced photocatalytic oxidation of nitrogen. The optimized MIL-100(Fe)/ $\mathrm{Ti}_{3} \mathrm{C}_{2}$ composite loaded with $15 \% \mathrm{Ti}_{3} \mathrm{C}_{2}$ delivered the largest visible photocatalytic efficiency of $57.92 \%$, which is three fold higher than MIL-100(Fe). Benefiting from the black body effect of $\mathrm{Ti}_{3} \mathrm{C}_{2}$ MXene, an enhanced light-harvesting ability and photothermal effect were achieved. This work serves as an example that $\mathrm{Ti}_{3} \mathrm{C}_{2}$ MXene can be regarded as a significant material for application in the photocatalytic nitrogen fixation field.

Although DFT theoretical calculations confirm that MXene is a potential catalyst for nitrogen reduction [37], studies on MXene-based materials in photocatalytic nitrogen fixation are relatively rare. Thus, more attention should be paid to experimental and theoretical research in this field.

\subsection{Photocatalytic oxidation of organic pollutant}

MXenes have been widely used as co-catalysts in the photocatalytic removal of organic pollutants (Table 2) because of their peculiar layered framework and superior electrical characteristics. Numerous environmental pollutants, which include organic dyes, antibiotics, and volatile organic compounds (VOCs), have been reported as having been removed by MXene-based photocatalysts $[41,98,99]$.

Although the photocatalytic degradation of $\mathrm{MB}$ and $\mathrm{AB} 80$ dye over $\mathrm{Ti}_{3} \mathrm{C}_{2} \mathrm{~T}_{x}$ was accelerated under UV irradiation, the photocatalytic degradation ability of dyes using MXene alone is not evident [40]. In most cases, MXene is used as a co-catalyst in photocatalysis. Peng et al. [64] synthesized a composite of 2D $\mathrm{Ti}_{3} \mathrm{C}_{2}$ and $\mathrm{TiO}_{2}$ exposing $\{001\}$ facets via the hydrothermal oxidation of $\mathrm{Ti}_{3} \mathrm{C}_{2}$ assisted by $\mathrm{NaBF}_{4}$ (Fig. 9A). Here, $\mathrm{Ti}_{3} \mathrm{C}_{2}$ can not 
Table 2

Summary of photocatalytic oxidation of organic pollutants on MXene-based photocatalysts.

\begin{tabular}{|c|c|c|c|c|c|c|c|}
\hline Catalyst & $\begin{array}{l}\text { Weight } \\
\text { (mg) }\end{array}$ & MXene & Light source & Pollutant & $\begin{array}{l}\text { Degradation rate or } \\
\text { rate constant }\end{array}$ & Effect of MXene & Ref. \\
\hline $\mathrm{BiOBr} / \mathrm{Ti}_{3} \mathrm{C}_{2}$ MXene & 50 & $\mathrm{Ti}_{3} \mathrm{C}_{2}$ & $\begin{array}{l}\text { 300-W Xe lamp } \\
\text { (420 nm filter) }\end{array}$ & $\begin{array}{c}100 \mathrm{~mL} \text { RhB aqueous solution } \\
(20 \mathrm{mg} / \mathrm{L})\end{array}$ & $89.3 \%$ (TOC) & $\begin{array}{l}\text { Improved light absorption range } \\
\text { and accelerated the separation } \\
\text { of photo-induced carriers. }\end{array}$ & [102] \\
\hline$(001) \mathrm{TiO}_{2} / \mathrm{Ti}_{3} \mathrm{C}_{2}$ & 10 & $\mathrm{Ti}_{3} \mathrm{C}_{2}$ & $\begin{array}{l}\text { 300-W mercury } \\
\text { lamp }\end{array}$ & $\begin{array}{c}200 \mathrm{~mL} \text { MO aqueous solution } \\
(20 \mathrm{mg} / \mathrm{L})\end{array}$ & $97.4 \%(50 \mathrm{~min})$ & Acting as a reservoir of holes. & {$[64]$} \\
\hline $\mathrm{In}_{2} \mathrm{~S}_{3} / \mathrm{TiO}_{2} @ \mathrm{Ti}_{3} \mathrm{C}_{2} \mathrm{~T}_{\mathrm{x}}$ & 60 & $\mathrm{Ti}_{3} \mathrm{C}_{2} \mathrm{~T}_{\mathrm{x}}$ & $\begin{array}{l}\text { 300-W Xenon lamp } \\
\text { (420 nm filter) }\end{array}$ & $\begin{array}{l}100 \mathrm{~mL} \text { MO solution } \\
(20 \mathrm{mg} / \mathrm{L})\end{array}$ & $92.1 \%(1 \mathrm{~h})$ & $\begin{array}{l}\text { Type-II heterojunction and } \\
\text { Schottky junction prolonging } \\
\text { electron lifetime. }\end{array}$ & [101] \\
\hline $\mathrm{TiO}_{2} / \mathrm{Ti}_{3} \mathrm{C}_{2}$ & 100 & $\mathrm{Ti}_{3} \mathrm{C}_{2}$ & $\begin{array}{l}\text { 175-W mercury } \\
\text { lamp }\end{array}$ & $100 \mathrm{~mL}$ MO (20 mg/L) & $98 \%$ (30 min) & $\begin{array}{c}\text { Efficient electron-hole separa- } \\
\text { tion }\end{array}$ & [103] \\
\hline $\mathrm{TiO}_{2} @ \mathrm{Ti}_{3} \mathrm{C}_{2} / \mathrm{g}-\mathrm{C}_{3} \mathrm{~N}_{4}$ & 100 & $\mathrm{Ti}_{3} \mathrm{C}_{2}$ & $\begin{array}{l}\text { 300-W Xe lamp } \\
\text { (400 nm filters) }\end{array}$ & $\begin{array}{l}100 \mathrm{~mL} \text { aniline }(20 \mathrm{mg} / \mathrm{L}) ; \\
100 \mathrm{~mL} \text { RhB }(10 \mathrm{mg} / \mathrm{L})\end{array}$ & $\begin{array}{l}\text { 74.6\% (aniline) } \\
99.9 \% \text { (RhB) }\end{array}$ & $\begin{array}{l}\text { Excellent supporter of migrating } \\
\text { electrons. }\end{array}$ & {$[104]$} \\
\hline$\alpha-\mathrm{Fe}_{2} \mathrm{O}_{3} / \mathrm{Ti}_{3} \mathrm{C}_{2}$ & 20 & $\mathrm{Ti}_{3} \mathrm{C}_{2}$ & $\begin{array}{l}500 \mathrm{~W} \text { Xe lamp } \\
\text { (420 nm filter) }\end{array}$ & $100 \mathrm{~mL} \mathrm{RhB}(10 \mathrm{mg} / \mathrm{L})$ & $98 \%(2 \mathrm{~h})$ & $\begin{array}{l}\text { Anchoring } \alpha-\mathrm{Fe}_{2} \mathrm{O}_{3} \text { and enhanc- } \\
\text { ing light absorption. }\end{array}$ & {$[100]$} \\
\hline Ceria/ $\mathrm{Ti}_{3} \mathrm{C}_{2}$ & 50 & $\mathrm{Ti}_{3} \mathrm{C}_{2}$ & 500-W Hg lamp & $50 \mathrm{ml} \mathrm{RhB}$ solution $(20 \mathrm{mg} / \mathrm{L})$ & $75 \%(1.5 \mathrm{~h})$ & $\begin{array}{l}\text { Improving the utilization of } \\
\text { optical energy. }\end{array}$ & [105] \\
\hline $\mathrm{Bi}_{2} \mathrm{WO}_{6} / \mathrm{Ti}_{3} \mathrm{C}_{2}$ & 20 & $\mathrm{Ti}_{3} \mathrm{C}_{2}$ & $\begin{array}{l}\text { 300-W xenon lamp } \\
\text { (400 nm filter) }\end{array}$ & $\begin{array}{c}5 \mu \mathrm{L} \mathrm{HCHO} \\
5 \mu \mathrm{L} \mathrm{CH}_{3} \mathrm{COCH}_{3} \\
\text { was injected into the reactor } \\
\text { and vaporized }\end{array}$ & $\begin{array}{c}\mathrm{CO}_{2} \text { production: } 72.8 \\
\mu \mathrm{mol} / \mathrm{g} / \mathrm{h}(\mathrm{HCHO}) \\
85.3 \mu \mathrm{mol} / \mathrm{g} / \mathrm{h} \\
\left(\mathrm{CH}_{3} \mathrm{COCH}_{3}\right)\end{array}$ & $\begin{array}{l}\text { Increasing VOC adsorption and } \\
\text { trapping photo-induced elec- } \\
\text { trons. }\end{array}$ & {$[99]$} \\
\hline $\mathrm{TiO}_{2} / \mathrm{Ti}_{3} \mathrm{C}_{2} \mathrm{~T}_{x}$ & 10 & $\mathrm{Ti}_{3} \mathrm{C}_{2} \mathrm{~T}_{x}$ & $\begin{array}{c}\text { UV or } \\
\text { Solar light simulator }\end{array}$ & $\begin{array}{l}10 \mathrm{ml} \text { Carbamazepine } \\
(5 \mathrm{mg} / \mathrm{L})\end{array}$ & $\begin{array}{c}\text { 98.67\% (UV) } \\
55.83 \% \text { (Solar light) }\end{array}$ & $\begin{array}{l}\text { Affecting the degradation mech- } \\
\text { anism and reaction route. }\end{array}$ & [106] \\
\hline $\mathrm{Ag}_{3} \mathrm{PO}_{4} / \mathrm{Ti}_{3} \mathrm{C}_{2}$ & 20 & $\mathrm{Ti}_{3} \mathrm{C}_{2}$ & $\begin{array}{l}300 \mathrm{~W} \text { Xe lamp } \\
\text { (420 nm filter) }\end{array}$ & $\begin{array}{c}\text { MO dye } \\
\text { 2,4-dinitrophenol, } \\
\text { tetracycline hydrochloride, } \\
\text { Thiamphenicol } \\
\text { chloramphenicol }\end{array}$ & $\begin{array}{c}0.094 \mathrm{~min}^{-1} \\
0.005 \mathrm{~min}^{-1} \\
0.32 \mathrm{~min}^{-1} \\
0.0042 \mathrm{~min}^{-1} \\
0.025 \mathrm{~min}^{-1} \\
\end{array}$ & $\begin{array}{l}\text { Electron sink to facilitate the } \\
\text { separation of carriers, and a } \\
\text { built-in electric field to inhibit the } \\
\text { photo-corrosion of } \mathrm{Ag}_{3} \mathrm{PO}_{4} \text {. }\end{array}$ & {$[41]$} \\
\hline
\end{tabular}

only provide the $\mathrm{Ti}$ source to produce high energy $\mathrm{TiO}_{2}$ nanosheets, but it also serves as the sink for photo-generated holes through the hole trapping performed by the Schottky junction, resulting in a highly efficient separation efficiency of photocarriers (Figs. 9B and Fig. 9C). Quenching experiments showed that hydroxyl radicals are the main reactive oxygen species (ROSs) responsible for the degradation of MO dye (Fig. 9D). In addition, the prepared $\{001\} \mathrm{TiO}_{2} / \mathrm{T}_{3} \mathrm{C}_{2}$ MXene exhibited excellent stability in photocatalysis (Fig. 9E).

In addition to $\mathrm{TiO}_{2}, 2 \mathrm{D} \alpha-\mathrm{Fe}_{2} \mathrm{O}_{3}$ is also employed to coat materials with $\mathrm{Ti}_{3} \mathrm{C}_{2}$. In 2018, Zhang et al. [100] reported an $\alpha-\mathrm{Fe}_{2} \mathrm{O}_{3} / \mathrm{Ti}_{3} \mathrm{C}_{2}$ MXene composite using a simple ultrasonic assisted assembly strategy. The UV-vis DRS spectra demonstrated that the visible light absorption of $\alpha-\mathrm{Fe}_{2} \mathrm{O}_{3} / \mathrm{Ti}_{3} \mathrm{C}_{2}$ is markedly red-shifted, and the increased absorption in the visible light region is due to the interaction between $\mathrm{Ti}_{3} \mathrm{C}_{2}$ and $\alpha-\mathrm{Fe}_{2} \mathrm{O}_{3}$. The $\alpha-\mathrm{Fe}_{2} \mathrm{O}_{3} / \mathrm{Ti}_{3} \mathrm{C}_{2}$ composite photocatalyst shows enhanced photocatalytic activity towards RhB degradation and excellent recycling stability under visible light irradiation. Overall, the high degradation rate was mainly attributed to the synergistic effects of strong visible light absorption and excellent charge separation efficiency. This study showed that $\mathrm{Ti}_{3} \mathrm{C}_{2}$ can be employed as an ideal substrate for anchoring other semiconductor photocatalysts.

Aside from constructing a binary heterojunction, novel ternary quasi-core-shell structured $\mathrm{In}_{2} \mathrm{~S}_{3} / \mathrm{TiO}_{2} @ \mathrm{Ti}_{3} \mathrm{C}_{2} \mathrm{~T}_{x}$ MXene composites have also been synthesized, and these showed outstanding photocatalytic performance towards the degradation of methyl orange dye [101]. The double heterojunction (type-
II heterojunction and Schottky junction) was constructed in the composite, making it beneficial in prolonging the lifetime of carriers and the generation of free radicals. In addition, the catalytic performance of MXenes can be steered by doping, morphology, or composition modifications.

Along with dyes, some drugs, such as tetracycline hydrochloride, thiamphenicol, and chloramphenicol have been proven capable of photocatalytic degradation by $\mathrm{Ag}_{3} \mathrm{PO}_{4} / \mathrm{Ti}_{3} \mathrm{C}_{2}$ MXene [41]. Research has discovered that $\mathrm{Ti}_{3} \mathrm{C}_{2}$ can dramatically boost photocatalytic performance and repeatability even more than graphene oxide in this system. Huang et al. [99] showed that $\mathrm{Ti}_{3} \mathrm{C}_{2}$ MXene nanoparticles can be electrostatically adsorbed on the surface of $\mathrm{Bi}_{2} \mathrm{WO}_{6}$ for the efficient removal of VOCs. The optimized $\mathrm{Bi}_{2} \mathrm{WO}_{6} / \mathrm{Ti}_{3} \mathrm{C}_{2}$ catalyst revealed 2- and 6.6-fold higher reactivity in the photocatalytic degradation of $\mathrm{HCHO}$ and $\mathrm{CH}_{3} \mathrm{COCH}_{3}$ when compared with pristine $\mathrm{Bi}_{2} \mathrm{WO}_{6}$ (Fig. 9F). Notably, such excellent catalytic performance could be attributed to the favorable adsorption of VOCs and the superior photo-generated carrier separation efficiency of $\mathrm{Ti}_{3} \mathrm{C}_{2}$ MXene.

\section{Summary and outlook}

In this review, we summarized the recent progress of semiconductor photocatalysis using MXenes as co-catalysts and discussed the synthesis and possible mechanisms of MXene-based photocatalysts, indicating the following:

(1) The introduction of MXenes has been shown to improve the reactivity of semiconductor photocatalysis during wa- 

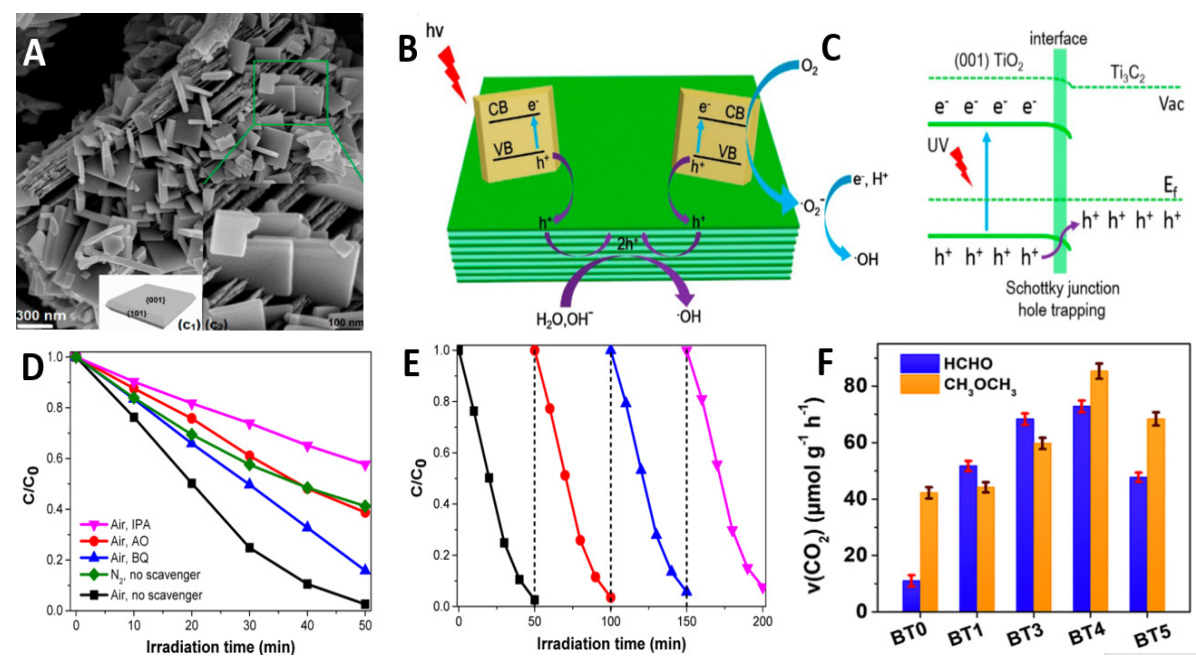

Fig. 9. SEM image of exposing $\{001\} \mathrm{TiO}_{2} / \mathrm{T}_{3} \mathrm{C}_{2}$ MXene (A), charge-transfer path of $\{001\} \mathrm{TiO}_{2} / \mathrm{T}_{3} \mathrm{C}_{2} \mathrm{MXene}(\mathrm{B})$, schematic band alignments and charge flows at $\{001\} \mathrm{TiO}_{2} / \mathrm{T}_{3} \mathrm{C}_{2}$ MXene interface (C), effects of scavengers on the degradation of $\mathrm{MO}$ with $\{001\} \mathrm{TiO}_{2} / \mathrm{Ti}_{3} \mathrm{C}_{2}$ under UV light irradiation (D), stability test for $\{001\} \mathrm{TiO}_{2} / \mathrm{Ti}_{3} \mathrm{C}_{2}$ toward $\mathrm{MO}$ degradation (E) [64], and histogram of $\mathrm{CO}_{2}$ production rate in photocatalytic oxidation of $\mathrm{HCHO}$ and $\mathrm{CH}_{3} \mathrm{COCH}_{3}$ over $\mathrm{Bi}_{2} \mathrm{WO}_{6}$ under the irradiation of visible light (F) [99].

ter-splitting to produce hydrogen. It can also increase the reduction of $\mathrm{CO}_{2}$ in producing solar fuels as well as increase nitrogen fixation and the oxidation of organic pollutants, which has the potential to solve environmental problems and the energy crisis.

(2) MXenes exhibit promising potential as cost-effective and noble-metal-free co-catalysts, as indicated by their electronic conductivity as well as the theoretical calculations for Gibbs free energy for their photocatalytic application.

(3) MXenes have a unique two-dimensional layered structure, which can provide abundant sites for the adsorption and activation of targets.

(4) MXenes can function as electron sinks to accelerate the migration of photo-generated electrons while inhibiting photo-generated carrier recombination, thereby promoting the process of photocatalytic reaction. Currently, although significant advancements have been made in the study of MXenes as photocatalytic co-catalysts, there are still many problems that need to be solved.

(5) Although MXene-based catalysts exhibit higher photoreactivity than noble-metal-based photocatalysts, the photocatalytic applications have thus far mainly been focused on hydrogen production, $\mathrm{CO}_{2}$ reduction, and the degradation of organic pollutants in water. There are few studies related to air purification (degradation of gaseous pollutants), ammonia synthesis, and overall water splitting. Therefore, these subjects need more careful studies to be performed.

(6) Most importantly, some similar mechanisms were presented that explain the enhanced reactivity of MXene-based photocatalysts. However, the effects of MXenes are still under debate. Some researchers have suggested that it is graphene quantum dots-derived from $\mathrm{Ti}_{3} \mathrm{C}_{2}$ rather than $2 \mathrm{D} \mathrm{Ti}_{3} \mathrm{C}_{2}$ - that act as the real co-catalyst for $\mathrm{La}_{2} \mathrm{Ti}_{2} \mathrm{O}_{7} / \mathrm{Ti}_{3} \mathrm{C}_{2}$ composites during photocatalytic reactions [107]. With the development of modern instruments, we can apply some in-situ techniques such as in-situ DRIFTS to unveil the effects of MXenes as co-catalysts on photocatalysis.
(7) The majority of MXene preparation mainly relies on etching the A-layer of MAX using toxic HF or HF alternatives. The wastewater produced during the etching process has high toxicity and is strongly corrosive, which is harmful to the environment. Therefore, developing a safe and environmentally friendly MXene synthesis process is highly urgent.

(8) Although some theoretical results show that MXenes with functional groups can be applied as semiconductor photocatalysts, this has not yet been proven in experiments. Therefore, additional thorough explorations should be performed in this regard. Currently, MXenes are mainly used as co-catalysts and could be engineered for photoelectric performance by modifying their surface chemistries or the assignments of the surface groups related to the M atoms [40]. Understanding the specific functions of these terminated functional groups is necessary in the next stage of research toward improving the photocatalytic performance of MXene-based photocatalysts.

(9) Some updated techniques could be introduced to further improve the photocatalytic activity of MXene-based photocatalysts, such as the localized surface plasmon resonance effect $[1,108,109]$, defective engineering $[110,111]$, and single-atom catalysis $[112,113]$. These approaches can be used to improve light harvesting ability, stimulate the separation of photo-generated charge carriers, and provide unique active sites, which can further enhance the photoreactivity of MXene-based photocatalysts.

\section{References}

[1] L. Zhang, C. Yang, K. L. Lv, Y. C. Lu, Q. Li, X. F. Wu, Y. H. Li, X. F. Li, J. J. Fan, M. Li, Chin. J. Catal., 2019, 40, 755-764.

[2] X. Y. Liu, M. Ye, S. P. Zhang, G. C. Huang, C. H. Li, J. G. Yu, P. K. Wong, S. W. Liu, J. Mater. Chem. A, 2018, 6, 24245-24255.

[3] T. M. Su, Z. D. Hood, M. Naguib, L. Bai, S. Luo, C. M. Rouleau, I. N. Ivanov, H. B. Ji, Z. Z. Qin, Z. L. Wu, Nanoscale, 2019, 11, 8138-8149.

[4] T. M. Su, Q. Shao, Z. Z. Qin, Z. H. Guo, Z. L. Wu, ACS Catal., 2018, 8, 


\section{Graphical Abstract}

Chin. J. Catal., 2021, 42: 3-14 doi: 10.1016/S1872-2067(20)63630-0

\section{MXenes as noble-metal-alternative co-catalysts in photocatalysis}

Kaining Li, Sushu Zhang, Yuhan Li *, Jiajie Fan, Kangle Lv*

South-Central University for Nationalities;

Chongqing Technology and Business University;

Zhengzhou University

This mini-review presents recent achievements in research on MXenes as co-photocatalysts in $\mathrm{H}_{2}$ production, $\mathrm{CO}_{2}$ reduction, $\mathrm{N}_{2}$ fixation, and organic degradation. The structures, synthesis, and mechanisms of MXenes as co-photocatalysts are also summarized and discussed.

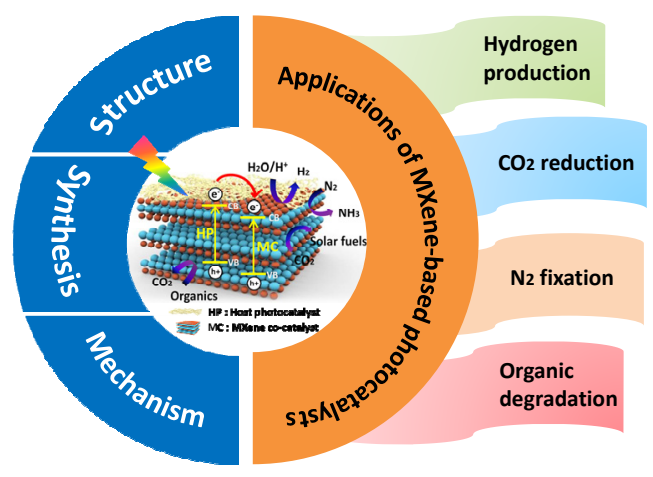

2253-2276.

[5] Y. Xia, B. Cheng, J. J. Fan, J. G. Yu, G. Liu, Small, 2019, 15, 1902459.

[6] D. X. Tan, J. L. Zhang, J. B. Shi, S. P. Li, B. X. Zhang, X. N. Tan, F. Y. Zhang, L. F. Liu, D. Shao, B. X. Han, ACS Appl. Mater. Interfaces, 2018, 10, 24516-24522.

[7] H. J. Yu, J. Y. Li, Y. H. Zhang, S. Q. Yang, K. L. Han, F. Dong, T. Y. Ma, H. W. Huang, Angew. Chem. Int. Ed., 2019, 58, 3880-3884.

[8] H. S. Huang, Y. Song, N. J. Li, D. Y. Chen, Q. F. Xu, H. Li, J. H. He, J. M. Lu, Appl. Catal. B, 2019, 251, 154-161.

[9] J. S. Cheng, Z. Hu, K. L. Lv, X. F. Wu, Q. Li, Y. H. Li, X. F. Li, J. Sun, Appl. Catal. B, 2018, 232, 330-339.

[10] C. Yang, Q. Li, Y. Xia, K. L. Lv, M. Li, Appl. Surf. Sci., 2019, 464, 388-395.

[11] M. J. Xu, Y. Chen, J. T. Qin, Y. W. Feng, W. Li, W. Chen, J. Zhu, H. X. Li, Z. F. Bian, Environ. Sci. Technol., 2018, 52, 13879-13886.

[12] Y. J. Yuan, H. W. Lu, Z. T. Yu, Z. G. Zou, ChemSusChem, 2015, 8, 4113-4127.

[13] H. Wang, R. Peng, Z. D. Hood, M. Naguib, S. P. Adhikari, Z. L. Wu, ChemSusChem, 2016, 9, 1490-1497.

[14] X. Q. An, W. Wang, J. P. Wang, H. Z. Duan, J. T. Shi, X. L. Yu, Phys. Chem. Chem. Phys., 2018, 20, 11405-11411.

[15] J. G. Yu, K. Wang, W. Xiao, B. Cheng, Phys. Chem. Chem. Phys., 2014, $16,11492-11501$.

[16] K. Iizuka, T. Wato, Y. Miseki, K. Saito, A. Kudo, J. Am. Chem. Soc., 2011, 133, 20863-20868.

[17] J. B. Cai, X. Q. Wu, S. X. Li, F. Y. Zheng, Appl. Catal. B, 2017, 201, 12-21.

[18] B. Anasori, M. R. Lukatskaya, Y. Gogotsi, Nat. Rev. Mater., 2017, 2, 16098.

[19] M. Naguib, O. Mashtalir, J. Carle, V. Presser, J. Lu, L. Hultman, Y. Gogotsi, M. W. Barsoum, ACS Nano, 2012, 6, 1322-1331.

[20] K. Hantanasirisakul, Y. Gogotsi, Adv. Mater., 2018, 30, 1804779.

[21] Z. Li, Y. Wu, Small, 2019, 15, 1804736.

[22] Y. Gogotsi, B. Anasori, ACS Nano, 2019, 13, 8491-8494.

[23] L. Yang, Y. Liu, R. Y. Zhang, W. Li, P. Li, X. Wang, Y. Zhou, Chin. J. Catal., 2018, 39, 646-653.

[24] P. Y. Kuang, B. C. Zhu, Y. L. Li, H. B. Liu, J. G. Yu, K. Fan, Nanoscale Horiz., 2018, 3, 317-326.

[25] J. X. Lv, Z. M. Zhang, J. Wang, X. L. Lu, W. Zhang, T. B. Lu, ACS Appl. Mater. Interfaces, 2019, 11, 2655-2661.

[26] Q. L. Xu, B. C. Zhu, B. C, J. G. Yu, M. H. Zhou, W. K. Ho, Appl. Catal. B, 2019, 255, 117770 .
[27] Y. Yao, Z. W. Jin, Y. H. Chen, Z. F. Gao, J. Q. Yan, H. B. Liu, J. Z. Wang, Y. L. Li, S. Z. Liu, Carbon, 2018, 129, 228-235

[28] Z. C. Zuo, D. Wang, J. Zhang, F. S. Lu, Y. L. Li, Adv. Mater., 2019, 31 1803762.

[29] M. Naguib, M. Kurtoglu, V. Presser, J. Lu, J. J. Niu, M. Heon, L. Hultman, Y. Gogotsi, M. W. Barsoum, Adv. Mater., 2011, 23, 4248-4253.

[30] M. Q. Zhao, X. Q. Xie, C. E. Ren, T. Makaryan, B. Anasori, G. X. Wang, Y. Gogotsi, Adv. Mater., 2017, 29, 1702410.

[31] J. F. Li, L. Han, Y. Q. Li, J. L. Li, G. Zhu, X. J. Zhang, T. Lu, L. K. Pan, Chem. Eng. J., 2020, 380, 122590.

[32] X. Tang, D. Zhou, P. Li, X. Guo, C. Y. Wang, F. Y. Kang, B. H. Li, G. X. Wang, ACS Cent. Sci., 2019, 5, 365-373.

[33] Y. Xie, M. Naguib, V. N. Mochalin, M. W. Barsoum, Y. Gogotsi, X. Yu, K. W. Nam, X. Q. Yang, A. I. Kolesnikov, P. R. C. Kent, J. Am. Chem. Soc., 2014, 136, 6385-6394.

[34] M. R. Lukatskaya, S. Kota, Z. F. Lin, M. Q. Zhao, N. Shpigel, M. D. Levi, J. Halim, P. L. Taberna, M. W. Barsoum, P. Simon, Y. Gogotsi, Nat. Energy, 2017, 2, 17105.

[35] S. Kumar, Y. J. Lei, N. H. Alshareef, M. A. Quevedo-Lopez, K. N. Salama, Biosens. Bioelectron., 2018, 121, 243-249.

[36] H. X. Zhang, Z. H. Wang, Q. X. Zhang, F. Wang, Y. Liu, Biosens. Bioelectron., 2019, 124-125, 184-190.

[37] J. H. Peng, X. Z, Chen, W. J. Ong, X. J. Zhao, N. Li, Chem, 2019, 5 , 18-50.

[38] P. Y. Kuang, M. He, B. C. Zhu, J. G. Yu, K. Fan, M. Jaroniec, J. Catal., 2019, 375, 8-20.

[39] Y. L. Sun, X. Meng, Y. Dall'Agnese, C. Dall'Agnese, S. N. Duan, Y. Gao, G. Chen, X. F. Wang, Nano-Micro Lett., 2019, 11, 79.

[40] O. Mashtalir, K. M. Cook, V. N. Mochalin, M. Crowe, M. W. Barsoum, Y. Gogotsi, J. Mater. Chem. A, 2014, 2, 14334-14338.

[41] T. Cai, L. L. Wang, Y. T. Liu, S. Q. Zhang, W. Y. Dong, H. Chen, X. Y. Yi, J. L. Yuan, X. N. Xia, C. B. Liu, S. L. Luo, Appl. Catal. B, 2018, 239, 545-554.

[42] Z. P. Zeng, Y. B. Yan, J. Chen, P. Zan, Q. H. Tian, P. Chen, Adv. Funct. Mater., 2019, 29, 1806500.

[43] S. W. Cao, B. J. Shen, T. Tong, J. W. Fu, J. G. Yu, Adv. Funct. Mater., 2018, 28, 1800136.

[44] Q. X. Liu, L. H. Ai, J. Jiang, J. Mater. Chem. A, 2018, 6, 4102-4110.

[45] T. M. Su, R. Peng, Z. D. Hood, M. Naguib, I. N. Ivanov, J. K. Keum, Z. Z. Qin, Z. H. Guo, Z. L. Wu, ChemSusChem, 2018, 11, 688-699.

[46] J. B. Pang, R. G. Mendes, A. Bachmatiuk, L. Zhao, H. Q. Ta, T. Gem- 
ming, H. Liu, Z. F. Liu, M. H. Rummeli, Chem. Soc. Rev., 2019, 48, 72-133.

[47] L. Verger, C. Xu, V. Natu, H. M. Cheng, W. C. Ren, M. W. Barsoum, Curr. Opin. Solid State Mater. Sci., 2019, 23, 149-163.

[48] H. Kim, Z. W. Wang, H. N. Alshareef, Nano Energy, 2019, 60, 179-197.

[49] B. M. Jun, S. Kim, J. Y. Heo, C. M. Park, N. Her, M. Jang, Y. Huang, J. Han, Y. Yoon, Nano Res., 2018, 12, 471-487.

[50] M. Alhabeb, K. Maleski, B. Anasori, P. Lelyukh, L. Clark, S. Sin, Y. Gogotsi, Chem. Mater., 2017, 29, 7633-7644.

[51] R. M. Ronchi, J. T. Arantes, S. F. Santos, Ceram. Int., 2019, 45, 18167-18188.

[52] M. Ghidiu, M. R. Lukatskaya, M. Q. Zhao, Y. Gogotsi, M. W. Barsoum, Nature, 2014, 516, 78-81.

[53] A. Lipatov, M. Alhabeb, M. R. Lukatskaya, A. Boson, Y. Gogotsi, A. Sinitskii, Adv. Electron. Mater., 2016, 2, 1600255.

[54] P. Urbankowski, B. Anasori, T. Makaryan, D. Er, S. Kota, P. L. Walsh, M. Q. Zhao, V. B. Shenoy, M. W. Barsoum, Y. Gogotsi, Nanoscale, 2016, 8, 11385-11391.

[55] O. Mashtalir, M. Naguib, V. N. Mochalin, Y. Dall'Agnese, M. Heon, M. W. Barsoum, Y. Gogotsi, Nat. Commun., 2013, 4, 1716.

[56] H. L. Chia, C. C. Mayorga-Martinez, N. Antonatos, Z. Sofer, J. J. Gonzalez-Julian, R. D. Webster, M. Pumera, Anal. Chem., 2020, 2452-2459.

[57] A. H. Feng, Y. Yu, F. Jiang, Y. Wang, L. Mi, Y. Yu, L. X. Song, Ceram. Int., 2017, 43, 6322-6328.

[58] C. Yang, Q. Y. Tan, Q. Li, J. Zhou, J. J. Fan, B. Li, J. Sun, K. L. Lv, Appl. Catal. B, 2020, 268, 118738.

[59] F. Shahzad, M. Alhabeb, C. B. Hatter, Babak Anasori, S. M. Hong, C. M. Koo, Y. Gogotsi, Science, 2016, 353, 1137-1140.

[60] Y. L. Sun, D. Jin, Y. Sun, X. Meng, Y. Gao, Y. Dall'Agnese, G. Chen, X. F. Wang, J. Mater. Chem. A, 2018, 6, 9124-9131.

[61] M. H. Ye, X. Wang, E. Z. Liu, J. H. Ye, D. F. Wang, ChemSusChem, 2018, 11, 1606-1611.

[62] Y. Zhuang, Y. F. Liu, X. F. Meng, Appl. Surf. Sci., 2019, 496, 143647.

[63] X. Q. Xie, N. Zhang, Z. R. Tang, M. Anpo, Y. J. Xu, Appl. Catal. B, 2018, 237, 43-49.

[64] C. Peng, X. F. Yang, Y. H. Li, H. Yu, H. J. Wang, F. Peng, ACS Appl. Mater. Interfaces, 2016, 8, 6051-6060.

[65] J. H. Yang, D. G. Wang, H. X. Han,C. Li, Acc. Chem. Res., 2013, 46, 1900-1909.

[66] J. Z. Chen, X. J. Wu, L. S. Yin, B. Li, X. Hong, Z. X. Fan, B. Chen, C. Xue, H. Zhang, Angew. Chem. Int. Ed., 2015, 54, 1210-1214.

[67] Y. Z. Liu, H. Y. Zhang, J. Ke, J. Q. Zhang, W. J. Tian, X. Y. Xu, X. G. Duan, H. Q. Sun, M. O Tade, S. B. Wang, Appl. Catal. B, 2018, 228, 64-74.

[68] Z. Li, Y. N. Ma, X. Y. Hu, E. Z. Liu, J. Fan, Chin. J. Catal., 2019, 40, 434-445.

[69] A. Y. Meng, L. Y. Zhang, B. Cheng, J. G. Yu, Adv. Mater., 2019, 31, 1807660.

[70] Y. Fang, Y. Cao, Q. L. Chen, Ceram. Int., 2019, 45, 22298-22307.

[71] Y. J. Li, X. T. Deng, J. Tian, Z. Q. Liang, H. Z. Cui, Appl. Mater. Today, 2018, 13, 217-227.

[72] J. Y. Shen, J. Shen, W. J. Zhang, X. H. Yu, H. Tang, M. Y. Zhang, Zulfiqar, Q. Q. Liu, Ceram. Int., 2019, 45, 24146-24153.

[73] L. Cheng, X. Li, H. W. Zhang, Q. J. Xiang, J. Phys. Chem. Lett., 2019, 10, 3488-3494

[74] N. Tian, Y. H. Zhang, X. W. Li, K. Xiao, X. Du, F. Dong, G. I. N. Waterhouse, T. R. Zhang, H. W. Huang, Nano Energy, 2017, 38, 72-81.

[75] Y. Li, D. N. Zhang, X. H. Feng, Q. J. Xiang, Chin. J. Catal., 2020, 41, 21-30.

[76] Z. L. Guo, J. Zhou, L. G. Zhu, Z. M. Sun, J. Mater. Chem. A, 2016, 4,
11446-11452.

[77] J. S. Cheng, Z. Hu, Q. Li, X. F. Li, S. Fang, X. F. Wu, M. Li, Y. B. Ding, B. Liu, C. J. Yang, L. L. Wen, Y. Liu, K. L. Lv, Appl. Catal. B, 2019, 245, 197-206.

[78] B. Q. Wang, Y. Ding, Z. R. Deng, Z. H. Li, Chin. J. Catal., 2019, 40, 335-342.

[79] P. Wang, S. Q. Xu, F. Chen, H. G. Yu, Chin. J. Catal., 2019, 40, 343-351.

[80] W. Zhang, H. W. Zhang, J. Z. Xu, H. Q. Zhuang, J. L. Long, Chin. J. Catal., 2019, 40, 320-325.

[81] J. R. Ran, G. P. Gao, F. T. Li, T. Y. Ma, A. J. Du, S. Z. Qiao, Nat. Commun., 2017, 8, 13907.

[82] Y. L. Yang, D. N. Zhang, Q. J. Xiang, Nanoscale, 2019, 11, 18797-18805.

[83] Y. Li, D. N. Zhang, X. H. Feng, Y. L. Liao, Q. Y. Wen, Q. J. Xiang, Nanoscale Adv., 2019, 1, 1812-1818.

[84] Y. J. Li, Z. H. Yin, G. R. Ji, Z. Q. Liang, Y. J. Xue, Y. C. Guo, J. Tian, X. Z. Wang, H. Z. Cui, Appl. Catal. B, 2019, 246, 12-20.

[85] M. M. Shao, Y. F. Shao, J. W. Chai, Y. J. Qu, M. Y. Yang, Z. L. Wang, M. Yang, W. F. Ip, C. T. Kwok, X. Q. Shi, Z. G. Lu, S. J. Wang, X. S. Wang, H. Pan, J. Mater. Chem. A, 2017, 5, 16748-16756.

[86] Y. J. Li, L. Ding, Y. C. Guo, Z. Q. Liang, H. Z. Cui, J. Tian, ACS Appl. Mater. Interfaces, 2019, 11, 41440-41447.

[87] L. M. Wang, W. L. Chen, D. D. Zhang, Y. P. Du, R. Amal, S. Z. Qiao, J. B. Wu, Z. Y. Yin, Chem. Soc. Rev., 2019, 48, 5310-5349.

[88] S. L. Wang, M. Xu, T. Y. Peng, C. X. Zhang, T. Li, I. Hussain, J. Y. Wang, B. Tan, Nat. Commun., 2019, 10, 676.

[89] C. B. Bie, B. C. Zhu, F. Y. Xu, L. Y. Zhang, J. G. Yu, Adv. Mater., 2019, 31, 1902868

[90] F. Y. Xu, K. Meng, B. C. Zhu, H. B. Liu, J. S. Xu, J. G. Yu, Adv. Funct. Mater., 2019, 29, 1904256.

[91] J. X. Low, L. Y. Zhang, T. Tong, B. J. Shen, J. G. Yu, J. Catal., 2018, 361, 255-266.

[92] A. Z. Pan, X. Q. Ma, S. Y. Huang, Y. S. Wu, M. J. Jia, Y. M. Shi, Y. Liu, P. Wangyang, L. He, Y. Liu, J. Phys. Chem. Lett., 2019, 10, 6590-6597.

[93] X. L. Xue, R. P. Chen, C. Z. Yan, Y. Hu, W. J. Zhang, S. Y. Yang, L. B. Ma, G. Y. Zhu, Z. Jin, Nanoscale., 2019, 11, 10439-10445.

[94] F. Lü, S. Z. Zhao, R. J. Guo, J. He, X. Y. Peng, H. H. Bao, J. T. Fu, L. L. Han, G. C. Qi, J. Luo, X. L. Tang, X. J. Liu, Nano Energy, 2019, 61, 420-427.

[95] J. Z. Qin, X. Hu, X. Y. Li, Z. F. Yin, B. J. Liu, K. Lam, Nano Energy, 2019, 61, 27-35.

[96] C. Y. Hao, Y. Liao, Y. Wu, Y. J. An, J. N. Lin, Z. F. Gu, M. H. Jiang, S. Hu, X. T. Wang, J. Phys. Chem. Solids, 2020, 136, 109141.

[97] H. M. Wang, R. Zhao, J. Q. Qin, H. X. Hu, X. W. Fan, X. Cao, D. Wang, ACS Appl. Mater. Interfaces, 2019, 11, 44249-44262.

[98] X. M. Cheng, L. H. Zu, Y. Jiang, D. L. Shi, X. M. Cai, Y. H. Ni, S. J. Lin, Y. Qin, Chem. Commun., 2018, 54, 11622-11625.

[99] G. M. Huang, S. Z. Li, L. J. Liu, L. F. Zhu, Q. Wang, Appl. Surf. Sci., 2020, 503, 144183.

[100] H. L. Zhang, M. Li, J. L. Cao, Q. J. Tang, P. Kang, C. X. Zhu, M. J. Ma, Ceram. Int., 2018, 44, 19958-19962.

[101] H. Wang, Y. Wu, T. Xiao, X. Z. Yuan, G. M. Zeng, W. G. Tu, S. Y. Wu, H. Y. Lee, Y. Z. Tan, J. W. Chew, Appl. Catal. B, 2018, 233, 213-225.

[102] C. Liu, Q. X. Xu, Q. F. Zhang, Y. S. Zhu, M. W. Ji, Z. W. Tong, W. H. Hou, Y. Zhang, J. G. Xu, J. Mater. Sci., 2018, 54, 2458-2471.

[103] Y. P. Gao, L. B. Wang, A. G. Zhou, Z. Y. Li, J. K. Chen, H. Bala, Q. K. Hu, X. X. Cao, Mater. Lett., 2015, 150, 62-64.

[104] X. H. Ding, Y. C. Li, C. H. Li, W. T. Wang, L. Wang, L. J. Feng, D. Z. Han, J. Mater. Sci., 2019, 54, 9385-9396. 
[105] W. J. Zhou, J. F. Zhu, F. Wang, M. J. Cao, T. Zhao, Mater. Lett., 2017, 206, 237-240.

[106] A. Shahzad, K. Rasool, M. Nawaz, W. Miran, J. Jang, M. Moztahida, K. A. Mahmoud, D. S. Lee, Chem. Eng. J., 2018, 349, 748-755.

[107] B. Wang, M. Y. Wang, F. Y. Liu, Q. Zhang, S. Yao, X. L. Liu, F. Huang, Angew. Chem. Int. Ed., 2020, 59, 1914-1918.

[108] J. K. El-Demellawi, S. Lopatin, J. Yin, O. F. Mohammed, H. N. Alshareef, ACS Nano, 2018, 12, 8485-8493.

[109] X. Y. Dai, C. M. Song, C. Y. Qiu, L. M. Wu, Y. J. Xiang, IEEE Sens. J., 2019, 19, 1558-1748.
[110] Z. Hu, K. N. Li, X. F. Wu, N. Wang, X. F. Li, Q. Li, L. Li, K. L. Lv, Appl. Catal. $B, 2019,256,117860$.

[111] X. H. Sang, Y. Xie, M. W. Lin, M. Alhabeb, K. L. V. Aken, Y. Gogotsi, P. R. C. Kent, K. Xiao, R. R. Unocic, ACS Nano, 2016, 10, 9193-9200.

[112] Z. Hu, C. Yang, K. L. Lv, X. F. Li, Q. Li, J. J. Fan, Chem. Commun., 2020, 56, 1745-1748.

[113] D. Zhao, Z. Chen, W. J. Yang, S. J. Liu, X. Zhang, Y. Yu, W. C. Cheong, L. R. Zheng, F. Q. Ren, G. B. Ying, X. Cao, D. S. Wang, Q. Peng, G. X. Wang, C. Chen, J. Am. Chem. Soc., 2019, 141, 4086-4093.

\title{
非贵金属助催化剂MXene在光催化领域应用的研究进展
}

\author{
李开宁 ${ }^{\mathrm{a}}$, 张苏舒 $\mathrm{a}$ ，李宇涵, ${ }^{\mathrm{b},}$ ，范佳杰 ${ }^{\mathrm{c}}$, 吕康乐 ${ }^{\mathrm{a},{ }^{*}}$ \\ ${ }^{\mathrm{a}}$ 中南民族大学资源与环境学院, 催化转化与能源材料化学教育部重点实验室, 湖北武汉 430074

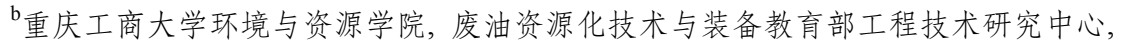 \\ 重庆市催化与环境新材料重点实验室, 重庆400067 \\ c郑州大学材料科学与工程学院, 河南郑州 450001
}

摘要: 环境友好型半导体光催化是当前最具前景的光催化技术之一, 它不仅能够将太阳能转化为化学能以解决能源危机, 还可以将污染物降解矿化从而解决环境问题. 但是, 传统的半导体光催化剂受限于光利用率低、光生载流子复合率高、稳 定性较差等几个方面, 无法达到理想的光催化效果. 在半导体光催化剂上负载助催化剂是提升光催化效率的有效策略之 一. 负载助催化剂能够增强光生电荷在半导体与助催化剂界面间的传输, 提供额外的催化活性位点, 增强光捕获能力, 因 而被广泛应用于光催化剂的改性. 目前广泛使用的贵金属助催化剂包括 $\mathrm{Au}, \mathrm{Ag}, \mathrm{Pt}, \mathrm{Ru}$ 等, 虽然这些贵金属助催化剂性能优 异, 但是它们存在储量少和成本高的问题, 严重影响其规模化应用. 因此, 开展高效且成本低廉的非贵金属助催化剂的研 究非常必要. 近来, 一种新型二维过渡金属材料(MXene)因其具有独特的二维层状结构、优异的导电性能、出色的光学和 热力学性质而成为催化领域的研究热点.

本文综述了有关非贵金属助催化剂MXene在光催化领域的最新研究进展, 内容包括: (1)MXene材料的体相与表面结 构特性; (2)薄层MXene的制备方法, 例如氢氟酸刻蚀法、氢氟酸替代物刻蚀法以及熔融氟盐刻蚀法; (3)MXene基复合光催 化剂的合成及改性策略, 包括机械混合、自组装、原位氧化等; (4)MXene辅助增强光催化活性机理. 论文还重点介绍了 MXene作为助催化剂在光催化领域中的应用, 包括光催化分解水产氢、光催化 $\mathrm{CO}_{2}$ 还原、光催化固氮以及有机污染物的光 催化降解. 最后, 论文分析了MXene基异质结光催化剂存在的问题与面临的挑战, 并对MXene助催化剂的未来发展进行了 展望. 主要观点包括: (1)关于光催化分解水、空气净化、合成氨领域的研究较少, 需要进一步开展; (2)MXene基异质结光 催化剂的反应机理仍存在争议, 需采用现代化仪器设备(包括原位表征技术)对其进行更为深入的探究; (3)目前, 大多数 MXene材料的制备都是通过强腐蚀性的氢氟酸或氢氟酸替代物刻蚀, 开发环境友好且高效的MXene制备方法迫在眉睫; (4)阐明MXene表面终端基团的作用有助于提升MXene基复合光催化剂的性能; (5)引入新的改性策略如局域表面等离子体 共振效应(LSPR)、缺陷调控、单原子催化(SAC)等来提高MXene基光催化剂的催化性能, 是未来MXene基复合催化剂的发 展方向.

关键词: 二维过渡金属材料; 光催化降解; 产氢; 二氧化碳还原; 固氮

收稿日期: 2020-03-27. 接受日期: 2020-05-02. 出版日期: 2021-01-05.

*通讯联系人. 电话: (027)67841369; 传真: (027)67843918; 电子信箱: lvkangle@mail.scuec.edu.cn

\#通讯联系人. 电话: (023)62768317; 电子信箱: lyhctbu@126.com

基金来源：国家自然科学基金(51672312, 51808080, 21373275); 中南民族大学中央高校基本科研业务费专项资金(CZT20016); 中 国“博士后创新人才支持计划” (BX20180056); 重庆市基础研究与前沿探索项目(cstc2018jcyjA3794); 中国博士后科学基金第64 批面上资助 “西部地区博士后人才资助计划” 项目(2018M643788XB); 重庆市教委项目(KJQN201800826, KJZDK201800801); 重 庆市留学人员回国创业创新支持计划(cx2018130); 重庆工商大学高层次人才引进项目(1856039).

本文的电子版全文由Elsevier出版社在ScienceDirect上出版(http://www.sciencedirect.com/science/journal/18722067). 